Ann. Sci. for., 1985, 42 (2), 113-142

\title{
Standing crop, production, and turnover of fine roots on dry, moderate, and wet sites of mature Douglas-fir in western Oregon
}

\author{
D. SANTANTONIO $" 1$ et R.K. HERMANN $\approx$ \\ Production Forestry Division, Forest Research Institute, \\ Private Bag, Rotorua, Nen Zealand \\ * Departments of Forest Science and Forest Management, \\ Oregon State University, Corvallis, Oregon 97331 USA
}

\begin{abstract}
Summary
Standing crops of live and dead fine $(<1 \mathrm{~mm}$ diameter) and small (1 to $5 \mathrm{~mm}$ diameter) roots in the top $75 \mathrm{~cm}$ of soil were sampled from March 1977 to September 1979 in dry, moderate, and wet habitats of mature Douglas-fir (Pseudotsuga menziesii). During this period, large and statistically significant changes in standing crops of fine roots occurred within short intervals $(<3$ months). Overall standing crops of small roots did not change significantly, nor were they statistically different overall. Standing crops of live roots $(2.5$ to $3.5 \mathrm{Mg} / \mathrm{ha})(+)$ were not statistically different among sites, but those of dead fine roots were $(10.7 \mathrm{Mg} / \mathrm{ha}$ on dry site, $4.1 \mathrm{Mg} /$ ha on wet).

On the basis of changes in standing crops of live and dead fine roots, we estimated fine-root production on the dry, moderate, and wet sites to be $6.5,6.3$, and $4.8 \mathrm{Mg} / \mathrm{ha} /$ year ; turnover to be $7.2,7.2$, and $5.5 \mathrm{Mg} / \mathrm{ha} /$ year; and decomposition to be $8.2,8.0$, and $6.9 \mathrm{Mg} / \mathrm{ha} /$ year. The effect of site conditions may bc indicated by the number of times that the mean standing crop of live fine roots turned over per year: 2.8 on the dry site, 2.0 on the moderate site, and 1.7 on the wet site. Cyclic death and replacement of fine roots in a succession of favorable microsites may be an adaptive strategy to maintain the largest number of active roots at a minimum metabolic cost. Results of this study confirm the importance of fine roots as a major pathway of carbon cycling in temperate forests.
\end{abstract}

Key words : Douglas-fir, Pseudotsuga menziesii, roots, fine roots, root production, root turnover, root decomposition, root grow'h, moisture stress.

(1) When this study was conducted, D. Santantonio was affiliated with the Department of Forest Science, Oregon State University, Corvallis, Oregon, U.S.A.

( + ) $\mathbf{M g} / \mathrm{ha}=$ millions de grammes par hectare $=$ tonnes $/$ ha.

(2) Requests for reprints should be sent to Forest Research Laboratory, Oregon State University, Corvallis, OR 97331, U.S.A. 


\section{Introduction}

Quantitative data on growth of roots in ferests are extremely limited. LYR \& Hoffmann (1967), Köstler el al. (1968), Fayl.F (1968), Sutton (1969, 1980), Head (1973), Riedacker (1976), Hermann (1977), Russel.l (1977), Caldweli. (1979), and Perry (1982) have reviewed the broad spectrum of literature pertaining to growth of tree roots. Despite this considerable body of information, our general understanding of roots lags far behind that of shoots. Previous investigations of root growth usually have been limited to seedlings or young trees grown in isolation. The relatively few studies of roots in forests have been hampered by serious technical difficulties. Seedlings and young trees grown in isolation differ fundamentally from large trees in a forest; we currently lack an adequate basis to extrapolate from one to the other.

Direct attempts to estimate root production and turnover in forests have been reported primarily within the last decade. These efforts to quantify stand productivity below ground have usually been part of large-scale ecosystem studies, such as those of the International Biological Program (HarRIS et al., 1980). Results of these studies indicate that fine-root dynamics are an important carbon pathway in temperate forest ecosystems (Ågren et al., 1980 ; Harris et al., 1980 ; Persson, 1983, Fogel, 1983). Whereas fine-root production and turnover have been compared for conifer and deciduous stands (Harris et al., 1977 ; MCCLAugherty et al., 1982), stands of different ages (Kalela, 1955; Persson, 1978, 1979, 1980 a ; Grier et al., 1981). and stands of different nutrient status (PERsson, $1980 \mathrm{~b}$; Keyes \& Grier, 1981), the effect of moisture stress has not been examined across a range of habitats within the same forest type.

SANTANTONIO et al. (1977) estimated the standing crop of roots $(<5 \mathrm{~mm}$ diameter in late summer for Watershed 10, a 10.2-ha watershed of old-growth Douglas-fir (Pseudotsuga menziesii [Mirb.] Franco) in western Oregon. When they calculated standing crops for the major habitat types within this watershed, they found over twice as much root material in the dry type along the ridgetops and upper southfacing slope as in the wet type along the stream and lower northfacing slope. Douglasfir appeared to exhibit a different strategy of fine-root growth in the dry habitat than in the wet one. Whether this difference reflected a higher overall standing crop of small and fine roots in the dry habitat or differences in the periodicity of root growth was unknown.

Little is known about how site conditions and the stage of stand development affect growth and development of small and fine roots in forests. Attempts to correlate changes in root growth directly to changes in environmental conditions have yielded inconclusive results (LyR \& HOFFMANN, 1967 ; HermanN, 1977 ; Russell, 1977). The extent to which perennial plants in different habitats exhibit selective strategies for the structure and growth of root systems remains unresolved (LYR \& HofFMANN, 1967 ; CaldDWell, 1979).

In this paper we present results of a 3-year investigation of the seasonal periodicity of fine-root growth in three stands of mature Douglas-fir which represent a gradicnt of moisture stress during the growing season. Objectives of the study include :

- defining seasonal fluctuations in standing crops of fine and small live and dead roots;

- comparing the periodicity of root-tip activity to changes in standing crops of fine roots;

- estimating fine-root production and turnover. 


\section{Study areas}

In the Pacific Northwest of the United States, Douglas-fir dominates extensive stands of dense forest across a broad range of environmental conditions (FrankLiN \& Dyrness, 1973 ; Waring \& Franklin, 1979; Franklin \& Waring, 1980). In general, temperature differentiates vegetational zones and summer moisture stress differentiates habitat types within zones (DYRness et al., 1974; ZoBri et al., 1976). A large range of habitat types which are dominated by Douglas-fir can exist even within a small watershed (GRIER \& LOGAN, 1977; HAWK, 1979).

We were able to locate three suitable natural stands of Douglas-fir which represented a broad gradient of moisture stress during summer. These stands are in mature forests located $90 \mathrm{~km}$ east of Eugene, Oregon, in the western Cascade Mountains $\left(44^{\prime \prime} 14^{\prime} \mathrm{N}-122^{\prime \prime} 13^{\prime} \mathrm{W}\right)$. They are low-elevation sites within or adjacent to the H.J. Andrews Experimental Ecological Reserve. Stands selected were of the same site quality class and of similar structure. All were past the stage of pole mortality by enough years for most dead stems to have fallen, and all had closed canopies and minimal understory biomass $(<2 \mathrm{Mg} / \mathrm{ha})$. Other selection criteria included practical sampling considerations such as deep soils without obstructions to sampling, gentle terrain, and year-round access. We felt reasonably confident that these stands were completely occupied, stable, and in equilibrium from one year to the next with respect to root and shoot competition.

Stands selected represent relatively dry, moderate, and wet habitat types within the Tsuga heterophylla series. We selected study sites based on vegetation type described by DYRNESS et al. (1974) and as related to environmental conditions by ZOBEL et al. (1976). The dry site is a T. heterophylla/Castanopsis chrysophylla habitat on a south-facing glacial terrace with a loam, $70 \mathrm{~cm}$ deep, overlaying a clay loam (Typic dystrocrept) (personal communication, H. Legard, Willamette National Forest, Eugene, O.R.). The moderate site is a $T$. heterophy/la/Rhododendron macrophyllum/Berberis nervosa habitat of northwest aspect on a mid-slope bench with a loam, $60 \mathrm{~cm}$ deep, overlaying a clay loam (Entic haplumbrept). The wet site is a T. heterophyllal Polystichum munitum-Oxalis oregana habitat on an old river terrace with a clay loam, $30 \mathrm{~cm}$ deep, overlaying a loamy clay (Typic haplohumult). Parent material of all sites is Andesitic tuff and breccia. Stand and site characteristics are outlined in table 1 .

Precipitation usually peaks in December-January when temperatures of air and soil are at minima, and temperature usually peaks in July-August when precipitation is at a minimum. Annual precipitation averages about $2000 \mathrm{~mm}$. Normally, only about 10 percent of the annual precipitation falls during the growing season, mili-May to October. Temperatures of soil and air are relatively mild throughout the winter. Snowfall persists only briefly at low elevations. Brief cold spells occur occasionally, but freezing of the soil is uncommon.

Finally, we must point out that, as a result of our selection criteria, the dry site did not represent the average dry Douglas-fir habitat in the western Cascade Mountains. Usually, such habitats are less productive sites, with shallow, rocky soils on upper south-facing slopes and ridgetops; most have a well-developed shrub understory because trees have been unable to occupy the site completely (DYRNEss et al., 1974). We decided that it was more important to select stands that were as comparable as possible and reasonably close to one another than to choose a more representative site. 
TABLE 1

Characteristics of the three stands selected for study.

Caractéristiques des trois peuplements choisis pour les recherches.

\begin{tabular}{|c|c|c|c|}
\hline Characteristic & Dry site & $\begin{array}{l}\text { Moderate } \\
\text { site }\end{array}$ & Wet site \\
\hline Elevation (m) & 610 & 790 & 520 \\
\hline Age (years) $\ldots \ldots \ldots \ldots \ldots \ldots \ldots \ldots \ldots \ldots \ldots$ & 70 & 170 & 120 \\
\hline Site quality* $\ldots \ldots \ldots \ldots \ldots \ldots \ldots \ldots$ & III & III & III \\
\hline Number of stems $/$ ha $>1 \mathrm{~cm}$ at breast height & 602 & 556 & 648 \\
\hline Mean diameter at breast height $(\mathrm{cm}) \ldots \ldots \ldots$ & 34 & 40 & 34 \\
\hline Mean height $(m) \ldots \ldots \ldots \ldots \ldots \ldots$ & 35 & 49 & 46 \\
\hline Basal area $\left(\mathrm{m}^{2} / \mathrm{ha}\right) \ldots \ldots \ldots \ldots \ldots$ & 60 & 78 & 74 \\
\hline Total aboveground biomass** ( $\mathrm{Mg} / \mathrm{ha})$. & 464 & 627 & 548 \\
\hline Foliage biomass $^{* * *}(\mathrm{Mg} / \mathrm{ha}) \ldots \ldots \ldots \ldots \ldots \ldots$ & 12 & 18 & 19 \\
\hline
\end{tabular}

\section{Methods}

A standard terminology for tree roots does not exist. Despite considerable differences in morphology and function, fine and coarse roots continue to be distinguished according to arbitrarily chosen diameters ranging from 1 to $10 \mathrm{~mm}$ (LESHEM, 1965; LYFORD, 1975 ; HERMANN, 1977 ; Fogel, 1983). For our study, we defined fine roots as having diameters $<1 \mathrm{~mm}$; small roots as having diameters of 1 to $5 \mathrm{~mm}$. We did not attempt to distinguish absorbing roots from solely structural ones. Standing crop of live roots equals biomass, and that of dead roots has been termed necromass by PERSSON (1978).

\subsection{Extraction of roots}

From March 1977 through September 1979, small and fine roots were sampled monthly at each site by extracting intact soil cores with a stecl tubular device driven into the ground. Sampling was by randomized block design. Each month nine soil cores, $5 \mathrm{~cm}$ in diameter, were taken from a sampling grid established on each site. The sampling grid consisted of an $18 \times 24 \mathrm{~m}$ plot divided into nine subplots (fig. 1). At each sample period, one sample $75 \mathrm{~cm}$ deep was taken from each of the nine subplots on each site. Obstructions to sampling, such as large roots and rocks, were infrequent $(<4$ percent). When they occurred, the sample was taken as close to the original location as possible, but never farther than $25 \mathrm{~cm}$ away. After soil core samples were taken, the holes were refilled with soil from the site. 


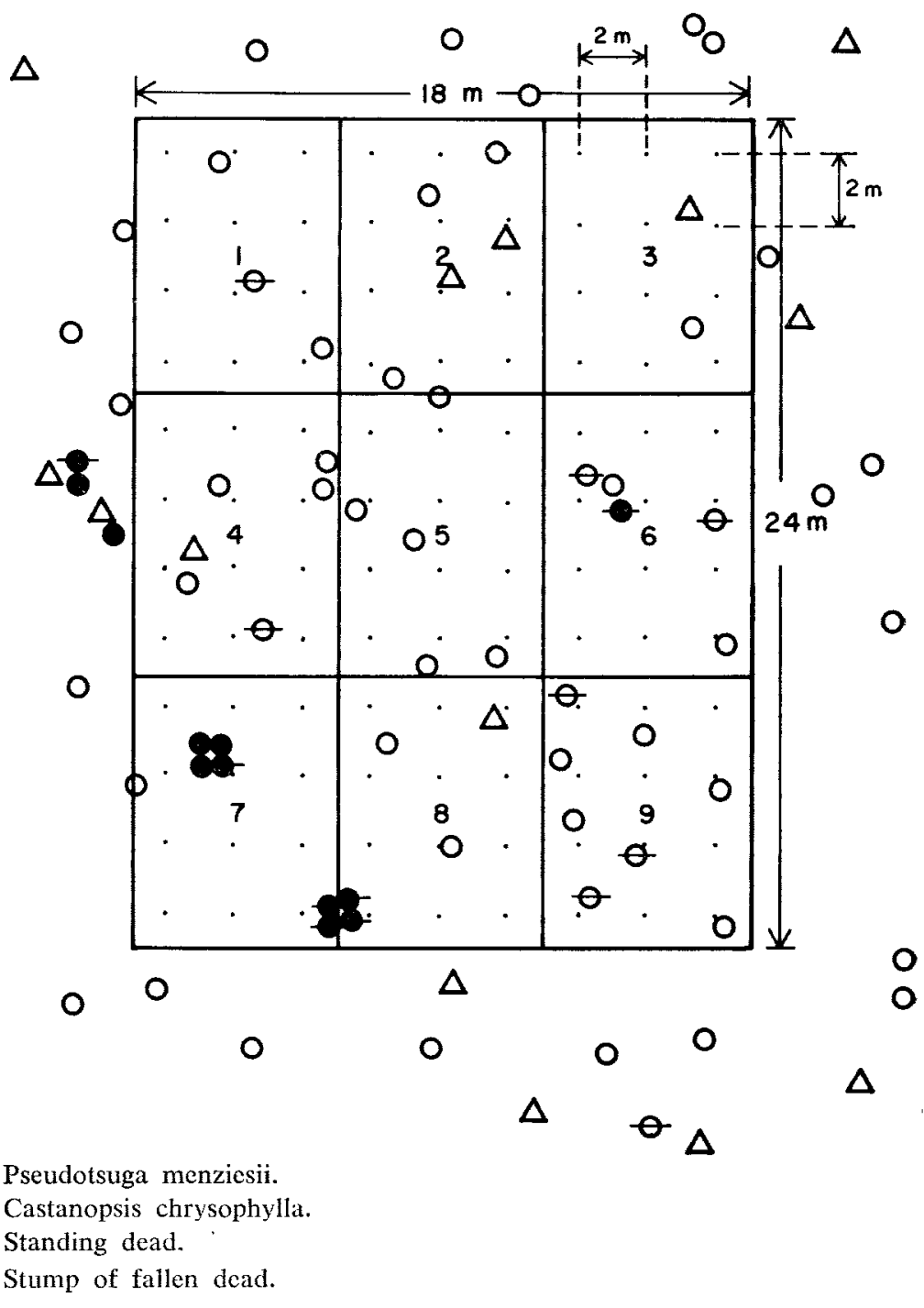

FIG. 1

Sampling grid superimposed over stem map of the dry site.

Quadrillage d'échantillonnage placé sur la carte des tiges (cas de la station sèche).

In April, May, and September 1979, «duplicate» soil samples were taken on the dry and wet sites to test the reliability of our sampling methods. These two samplings were taken at the same time, but in different locations as if they had been taken in successive sample periods. Thus, they were duplicates in time, but not precisely in space. Depth of sampling for these soil cores was reduced to $50 \mathrm{~cm}$. No duplicate 
samples were taken on the moderate site during April and May. For other purposes, the amount of roots in the 50 to $75 \mathrm{~cm}$ depth was estimated as the mean amount at these depths in the regular cores.

Intact soil cores were returned to the laboratory for processing. The soil column below the litter layer was cut into $10-\mathrm{cm}$ segments, which were refrigerated at $3{ }^{\circ} \mathrm{C}$ until live roots were removed. Briefly, processing consisted of hand sorting with forceps to remove live small and fine roots, which were cleaned by dipping them in an ultrasonic water bath. A combination of hand sorting, dry sieving, and separation with a modified seed blower was used to remove dead small and fine roots. We did not remove fungal sheaths from mycorrhizal roots. Roots extracted from each segment were classified as live or dead and grouped in size-classes by diameter. Samples were checked for errors and consistent removal of roots. All roots were oven-dried to constant weight at $70{ }^{\circ} \mathrm{C}$. Weights were recorded to the nearest 0.01 gram and converted to megagrams/hectare $\left(\mathrm{Mg} / \mathrm{ha}=10^{6} \mathrm{~g} / \mathrm{ha}=\mathrm{t} / \mathrm{ha}\right)$. While sorting out live roots, we also counted and recorded numbers of active root-tips as a means of assessing fine-root activity independent of changes in standing crop. We processed 846 soil cores over the course of the study at an average rate of 18 hours/core.

Preliminary analyses of data from the first 9 months indicated the necessity of estimating the variation associated with standing crops of fine and small roots. Bcginning with the tenth month, we sorted roots into categories $<1 \mathrm{~mm}$ and 1 to $5 \mathrm{~mm}$ in diameter for each sample individually. Before the tenth month, we sorted roots $<5 \mathrm{~mm}$ in diameter into size-classes only after pooling the nine individual samples.

We were unable to extract all dead fine-root fragments from the soil. We therefore used an 800-micron mesh sieve as the limit of our processing. Some dead mycorrhizal root-tips passed through this sieve, especially those from the dry site. These fragments were $<0.5 \mathrm{~mm}$ in diameter and $<1.5 \mathrm{~mm}$ in length. For practical reasons, we did not attempt to quantify this loss.

We defined the «litter layer» as the uppermost segment of the soil core sample. This segment consisted of a consolidated plug of litter and organic matter. The upper boundary was defined by brushing away loose, fresh litter before sampling; the lower boundary extended to, but did not include, the humus layer of the A-horizon, which was considered as part of the 0 to $10 \mathrm{~cm}$ segment.

Live roots were distinguished from dead ones on the basis of easily observable physical characteristics, thus leaving them intact for later analysis of surface area and nutrient content :

- Finest roots (mycorrhizal roots and root-tips). - Dead roots were brittle and fractured easily. Live roots were intact, flexible, and more or less succulent, depending on soil conditions.

- Fine roots (roots without secondary thickening). - Dead roots were brittle and fractured easily. Live roots were intact and flexible. Although cortical cells may have collapsed, the pericycle and stele under $20 \times$ magnification must have shown no signs of decomposition as indicated by discoloration, pitting, or fraying of the tissues in order to be classified as live.

- Larger roots (roots with secondary thickening). - Phloem must have shown no signs of decomposition under $20 \times$ magnification in order to be classified as live. Decomposition was first noticeable as discoloration and loss of turgor in phloem tissues, which often had a stringy appearance when teased with a needle. 
- New root-tips were light-colored, unsuberized, and succulent. Similar criteria have been used by other investigators (LYFORD, 1975 ; HARVEY et al., 1978 ; ROBERTS, 1976 ; Persson, 1978 ; Vogt et al., 1980 ; Grier et al., 1981 ; Keyes \& Grier, 1981 ; MCCl.augherty et al., 1982).

\subsection{Environmental measurements}

At each site, we measured air temperature, soil temperature, water potential of soil, and predawn water potential of xylem. Air temperature at $1 \mathrm{~m}$ above the forest floor and soil temperature at a depth of $20 \mathrm{~cm}$ were monitored continuously by a thermograph installed on each site. Water potentials at 10-, 20-, 40-, 60-, and 80-cm depths were measured each week during summer and early fall with nylon-impregnated gypsum blocks (Goltz et al., 1981) installed in the center of each subplot. Plant moisture stress was evaluated every 1 to 2 weeks during summer by measuring predawn xylem water potential on the same 2-m-tall understory trees (SCHOLANDER et al., 1965 ; RitCHIE \& HiNCKLEY, 1975). Water potentials have been reported as megaPascals ( $1 \mathrm{MPa}=10$ bars).

The McKenzie Ranger District of the U.S. Forest Service provided records of daily precipitation at the ranger station, which is $4 \mathrm{~km}$ from the dry site and $8 \mathrm{~km}$ from the moderate site. The H.J. Andrews Experimental Ecological Reserve provided records of daily precipitation at Watershed 2 , which is $2 \mathrm{~km}$ from the wet site.

\subsection{Statistical analyses}

Significance of changes in standing crops of small and fine roots was determined in a series of statistical tests. First, we calculated means and variances of standing crops in the upper $75 \mathrm{~cm}$ of soil at each sample period. For each site and root category, we then tested these variances with the F-max. test (SoKal \& RohlF, 1969, p. 371) to determine if we could assume that the variance was homogeneous at 95 percent confidence over the study period. Confirmation of homogeneity enabled us to test for the effect of sample period in a one way analysis of variance (HeLwig $\&$ Council, 1979 , p. 120). We used the pooled standard error with 160 degrees of freedom from the one-way analysis of variance to test if maximum and minimum means by site and root category were significantly different at 95 percent confidence according to the method of Student-Newman-Keuls (SoKal \& RoHLF, 1969, p. 239). If such a difference was confirmed, we then followed with a series of multiple range tests by the same method to determine which sample periods represented intermediate, relatively high and low values at 95 percent confidence.

We used estimates of error from the analysis of data for roots $<1 \mathrm{~mm}$ and 1 to $5 \mathrm{~mm}$ in diameter from sample periods 10 to 32 because we did not have estimates of variation for fine and small roots in the first 9 months. We considered this reasonable because variances for roots $<5 \mathrm{~mm}$ in diameter were homogeneous over the entire study period according to the F-max. test at 95 percent confidence (SokAL \& RohlF, 1969, p. 137).

Confidence and precision of sampling were evaluated in two ways :

- Percent coefficients of variation were calculated as the standard error of the mean divided by the mean and multiplied by 1.00 percent. Standard errors of means were calculated with the pooled standard error from the one-way analysis of variance. 
- Duplicate samples were evaluated by the $t$-test for differences between mean estimates of standing crops in the two samples (SoKal \& RoHLF, 1969, p. 221). Assuming homogeneity of variance, we calculated these confidence intervals by using the pooled variance of the duplicate samples with 16 degrees of freedom.

We were unable to assume homogeneity of variance for comparisons of overall standing crops between the wet and dry sites. Differences between these means were evaluated with the approximate t-test (Sokal \& RohLF, 1969, p. 376).

\subsection{Calculation of fine-root production and turnover}

Fine-root production and turnover can be estimated from changes in standing crops of live and dead fine roots from one sample period to the next. Our definitions were :

- Fine-root production - an increasc in the amount of live fine roots. This may appear as a simple increase in the standing crop of live fine roots, an increase in both live and dead fine roots, or an increase in the standing crop of dead fine roots not compensated by a decrease in live.

- Fine-root turnover - an increase in the amount of dead fine roots. This was quantified as the greater of either the increase in the standing crop of dead fine roots or the decrease of live fine roots.

- Decomposition - a decrease in the amount of dead fine roots. This would appear as a simple decrease in dead fine roots or a decrease in live fine roots not compensated by an increase in dead. Strictly speaking, we have not measured decomposition, but have estimated the disintegration of dead fine roots. Because of limitations in sample processing, we considered fragments of dead fine roots that pass through the 800 -micron sieve as soil organic matter.

We calculated fine-root production, turnover, and decomposition as summations of interval estimates. We developed the following equations, which we modified after PERSSON (1978) :

Production

$$
-\sum_{j=1}^{k}\left\{\max \cdot\left[(b+n)_{j}-O E_{j}, b_{j}-O E_{j}, 0\right]\right\}
$$

Turnover

$$
\geq \sum_{j} \sum_{1}^{k}\left\{\max .\left[|b \bar{j}|-O E_{j}, n_{j}-O E_{j}, 0\right]\right\}
$$

Decomposition

$$
\because \quad \sum_{j=1}^{k}\left\{\min .\left[(b+n)_{j}-O E_{j}, n_{j}-O E_{j}, 0\right]\right\} \mid
$$

where : $\mathbf{B}_{\mathbf{i}}=$ standing crop of live roots $=$ root biomass observed at a given sample period (i)

$\mathrm{N}_{\mathbf{i}}=$ standing crop of dead roots $=$ root necromass observed at a given sample period (i)

$b_{j}=B_{i+1}-B_{i},|b \bar{j}|=$ absolute value of decrement

$\mathrm{n}_{\mathrm{j}}=\mathrm{N}_{\mathrm{i}+1}-\mathrm{N}_{\mathrm{i}}$

$\mathbf{k}=$ no. of intervals $(\mathrm{j})$

$\mathrm{OE}_{\mathrm{j}}=$ overestimate of the interval 
Overestimates of the intervals $\left(\mathrm{OE}_{\mathrm{j}}\right)$ serve to correct for the likely contribution from random variation caused by the fact that estimates are based only on positive or negative changes in standing crops (see LINDGREN's discussion of the problem of overestimation in the appendix to Persson, 1978). We calculated $\mathrm{OE}_{\mathrm{j}}$ 's from a Monte Carlo-type simulation of sampling theoretical populations whose characteristics were based on data of sample period means and the pooled variance of the monthly samples. For each interval, 100 samplings $(n=9)$ were made without replacement and an overestimate was calculated as the difference between the observed change from one month to the next and the simulated one. $\mathrm{OE}_{\mathbf{j}}$ equals the summation of these overestimates for each interval divided by 100 . Correction for overestimation reduced gross annual estimates by 0.4 to $3.9 \mathrm{Mg} / \mathrm{ha} /$ year.

\section{Results}

\subsection{Environmental measurements}

Environmental conditions varied considerably during the three growing seasons and two intervening winters of the study. A wide range in moisture stress occurred during the summers as did unusually low temperatures during the winter of 1978-1979 (tabl. 2). Predawn xylem water potentials indicated differences in plant moisture

TABLE 2

Summary of environmental data from the three study sites by year (October through September).

Résumé des données de l'environnement des trois stations de cette étude suivant les années (octobre à septembre).

\begin{tabular}{|c|c|c|c|c|c|c|c|c|c|}
\hline \multirow{2}{*}{ Measurement } & \multicolumn{3}{|c|}{ Dry site } & \multicolumn{3}{|c|}{ Moderate site } & \multicolumn{3}{|c|}{ Wet site } \\
\hline & $76-77$ & $77-78$ & $78-79$ & $76-77$ & $77-78$ & $78-79$ & $76-77$ & | $77-78$ & 78-79 \\
\hline \multicolumn{10}{|l|}{$\begin{array}{l}\text { Air temperature } \\
1 \mathrm{~m} \text { (24-hour average) }\end{array}$} \\
\hline Minimum ("C) .... & 一 & -3 & -8 & $\overline{-3}$ & -6 & -8 & - & -5 & -8 \\
\hline Maximum (" $\mathrm{C})$ & 27 & 28 & 27 & 27 & 27 & 27 & 23 & 23 & 24 \\
\hline No. days $<0^{\prime \prime} \mathrm{C}$. & - & 6 & 34 & - & 12 & 43 & - & 5 & 49 \\
\hline No. days $>20^{\circ} \mathrm{C}$ & 25 & 30 & 38 & 19 & 21 & 22 & 8 & 10 & 7 \\
\hline \multicolumn{10}{|l|}{$\begin{array}{l}\text { Soil temperature } \\
20 \mathrm{~cm} \text { (24-hour average) }\end{array}$} \\
\hline Minimum ("C) $\ldots \ldots$ & - & 2 & 0 & $\overline{-}$ & 2 & 0 & - & 1 & 0 \\
\hline Maximum ( $\left.{ }^{\circ} \mathrm{C}\right)$ & 17 & 17 & 16 & 17 & 16 & 14 & 15 & 14 & 13 \\
\hline No. days $<3{ }^{\circ} \mathrm{C}$ & - & 5 & 84 & — & 43 & 125 & 一 & 34 & 112 \\
\hline No. days $>00^{\circ} \mathrm{C}$ & - & 0 & 5 & - & 0 & 27 & - & 0 & 5 \\
\hline $\begin{array}{l}\text { Minimum } \\
\text { soil water potential }\end{array}$ & & & & & & & & & \\
\hline $20 \mathrm{~cm}$ depth (MPa) & - & -0.20 & -0.72 & - & -0.15 & -0.51 & - & -0.26 & -0.70 \\
\hline $40 \mathrm{~cm}$ depth (MPa) & - & -0.07 & -0.51 & - & -0.13 & -0.43 & 一 & -0.16 & -0.56 \\
\hline $60 \mathrm{~cm}$ depth (MPa) .. & 一 & -0.05 & -0.44 & 一 & -0.08 & -0.34 & - & -0.12 & -0.53 \\
\hline $\begin{array}{l}\text { Minimum predawn xylem } \\
\text { water potential (MPa) }\end{array}$ & -1.8 & -0.8 & -2.0 & -1.0 & -0.7 & -1.3 & -0.8 & -0.7 & -1.0 \\
\hline
\end{tabular}


stress among sites as great as - 1.0 MPa. Such differences on the same site from one year to the next were as great as - 1.2 MPa. Not only were minimum temperatures of soil and air lower during the winter of 1978-1979, but 24-hour averages remained near freezing for many more days than during the more typical winter of 1977-1978. We encountered extensive soil freezing to $10 \mathrm{~cm}$ on all sites when the January and February samples were taken. On the moderate site, several icy patches as deep as $20 \mathrm{~cm}$ were encountered. We did not record any environmental data for the winter of 1976-1977.

The winter preceding our first sampling in March 1977 was very dry. Only half of the normally expected precipitation was recorded. Drought in the following growing season was not abnormally severe because spring and early fall rains were substantial. The first and third growing seasons were typically dry, and rainfall from mid-May to October approximately equalled the long-term average of about $200 \mathrm{~mm}$. Rainfall during the second growing season was nearly twice this amount and occurred at about 2 -week intervals, which effectively kept moisture stress at low levels.

\subsection{Reliability of estimates}

Reliability of our sampling methods was evaluated in terms of precision and reproducibility of estimates. As expected, we achieved greater precision in estimating fine roots than small ones (tabl. 3). Coefficients of variation for live fine roots

TABLE 3

Overall means, standard errors, and coefficients of variation of standing crops of live and dead fine and small roots.

Moyennes générales. erreurs standards, et coefficients de variation des quantités de très petites et pefites racines vivantes et mortes.

\begin{tabular}{|c|c|c|c|c|}
\hline \multirow{2}{*}{ Site and staristic } & \multicolumn{2}{|c|}{ Roots $<1 \mathrm{~mm}$ diameter } & \multicolumn{2}{|c|}{ Roots 1 to $5 \mathrm{~mm}$ diameter } \\
\hline & Live & Dead & Live & Dead \\
\hline $\begin{array}{l}\text { Dry } \\
\text { Mcan (Mg/ha)* .......... } \\
\text { Standard error }(\mathrm{Mg} / \mathrm{ha})^{* *} \ldots \\
\text { Coefficient of variation }(\%)\end{array}$ & $\begin{array}{l}2.53 \\
0.282 \\
13\end{array}$ & $\begin{array}{l}10.67 \\
1.204 \\
11\end{array}$ & $\begin{array}{l}3.29 \\
0.585 \\
21\end{array}$ & $\begin{array}{c}1.96 \\
0.408 \\
21\end{array}$ \\
\hline $\begin{array}{l}\text { Moderate } \\
\text { Mean }(\mathrm{Mg} / \mathrm{ha})^{*} \ldots \ldots \ldots \ldots \ldots \\
\text { Standard crror }(\mathrm{Mg} / \mathrm{ha})^{* *} \ldots \ldots \\
\text { Coefficient of variation }(\%) \ldots \ldots\end{array}$ & $\begin{array}{l}3.50 \\
0.422 \\
14\end{array}$ & $\begin{array}{c}8.16 \\
0.911 \\
11\end{array}$ & $\begin{array}{l}4.19 \\
0.650 \\
15\end{array}$ & $\begin{array}{c}1.33 \\
0.364 \\
23\end{array}$ \\
\hline $\begin{array}{l}\text { Wet } \\
\text { Mean }(\mathrm{Mg} / \mathrm{ha})^{*} \ldots \ldots \ldots \ldots \ldots \\
\text { Standard error }(\mathrm{Mg} / \mathrm{ha})^{*} \ldots \ldots \ldots \\
\text { Coefficient of variation }(\%) \ldots \ldots\end{array}$ & $\begin{array}{l}3.15 \\
0.315 \\
12\end{array}$ & $\begin{array}{c}4.05 \\
0.659 \\
16\end{array}$ & $\begin{array}{l}4.29 \\
0.801 \\
18\end{array}$ & $\begin{array}{c}1.14 \\
0.370 \\
27\end{array}$ \\
\hline
\end{tabular}

* Based on sample periods 1 to 32 exclusive of sample $B$ of the duplicates.

*:* Based on pooled estimate of error from one-way analysis of variance of sample periods 10 to 32. 
ranged from 12 to 14 percent, depending on site. For dead fine roots, this range was 11 to 16 percent. Coefficients of variation for small roots were 15 to 21 percent for live and 21 to 27 percent for dead. Tests of means revealed that differences between duplicate samples became significant only at probabilities $<88$ percent for fine roots and at $<84$ percent for small roots. These tests included a total of 24 comparisons of standing crops ( 2 sites $\times 4$ root categories $\times 3$ sample periods). Counts of new root-tips from duplicate samples proved significantly different at 99 percent confidence for one of six comparisons. The remaining differences between counts were not significant at probabilities $>74$ percent. Coefficients of variation for counts of new root-tips averaged 40 percent.

\subsection{Standing crops of small and fine roots}

Standing crops of live fine roots in the upper $75 \mathrm{~cm}$ of soil changed significantly on all sites. We observed increases as large as 160 percent and decreases as large as 70 percent over 3 -month periods (fig. 2 A). Although quite different in the first 6 months, the general shape of these curves was similar for all sites throughout the remainder of the study. One-way analysis of variance indicated that the effect of sample period was significant for all sites at probabilities exceeding 99 percent. Comparisons of means revealed that changes in standing crops which were significant at 95 percent confidence occurred within periods as short as 1 month. According to the Students-Newman-Kuels method, changes from one month to the next needed to be greater than $0.78,1.17$, and $0.87 \mathrm{Mg} /$ ha for the dry, moderate, and wet sites, respectively. Critical values, however, increase as the number of means in the interval increases. Changes for 3-month intervals must be greater than 1.02, 1.53, and $1.14 \mathrm{Mg} / \mathrm{ha}$ for the dry, moderate, and wet sites, respectively, in order to be significant at 95 percent confidence. By testing changes for different intervals, we confirmed that all major «peaks » and «valleys » of these curves were statistically significant at 95 percent confidence.

Seasonal changes of live fine roots during the first year were possibly confounded by a long-term decrease of about 50 percent. When we adjusted these means to remove this trend, changes in standing crop over the entire study generally indicated two major periods of fineroot accumulation during an annual cycle. We found relatively high levels in spring and fall and low levels in summer and winter. Some noteworthy exceptions exist :

- there was little or no accumulation of fine roots on the dry site during the fall of 1977 ;

- standing crops on all sites declined through the winter to a low in April 1978 ;

- a low in summer 1978 was lacking for all sites; of 1978 .

- the standing crop on the wet site remained unchanged throughout nearly all Of these, the last two probably resulted from low moisture stress during the 1978 growing season.

Changes in standing crop of dead fine roots were also significant on all sites. We observed increases as large as 210 percent and decreases as large as 60 percent over 3 -month periods (fig. $2 \mathrm{~B}$ ). One-way analysis of variance indicated that the effect of sample period was significant for all sites at probabilities exceeding 97 percent. Compa- 


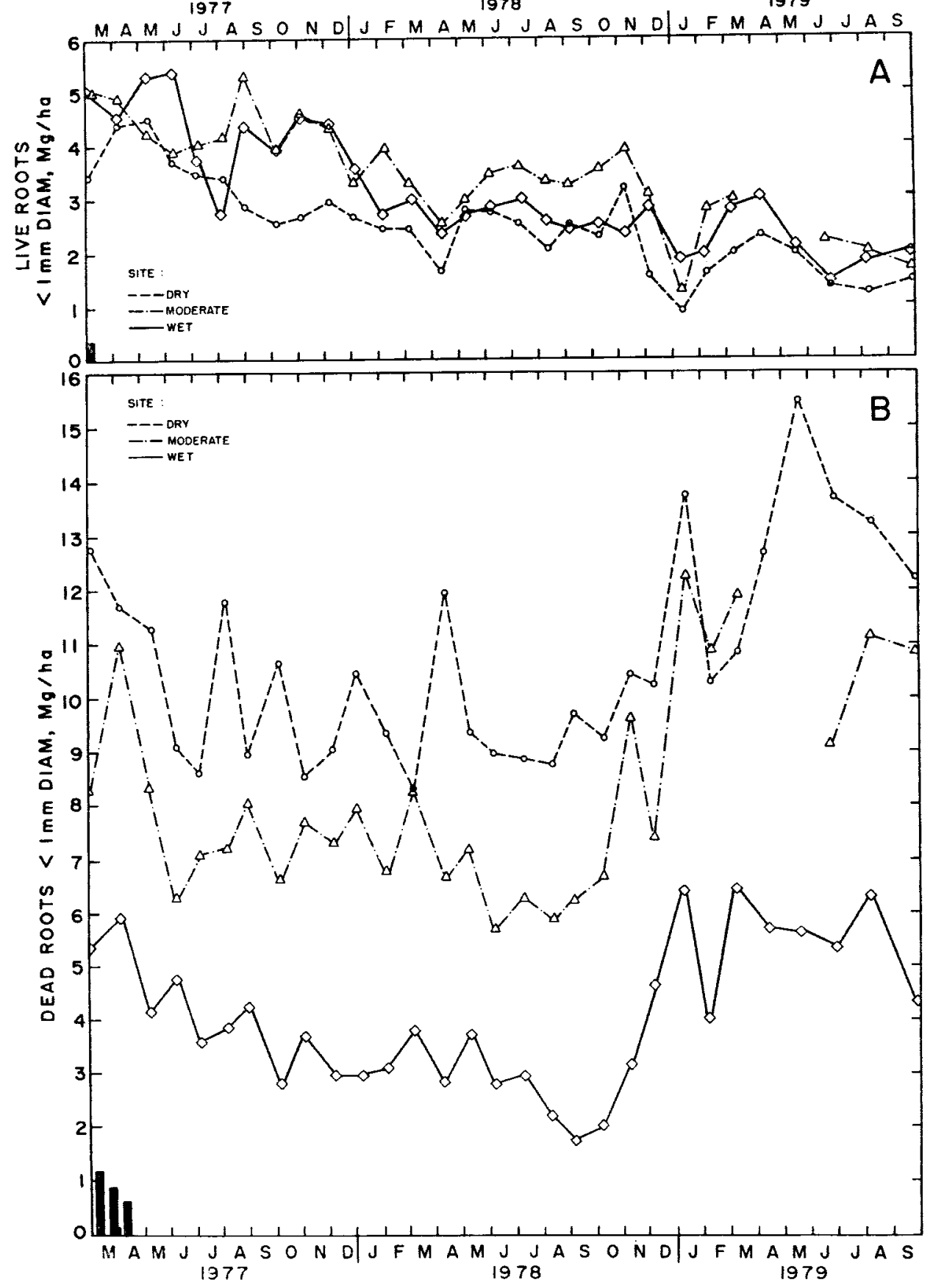

FIG. 2

Standing crops of live fine $(A)$ and dead fine (B) roots in the upper $75 \mathrm{~cm}$ of soil during the study period. For both graphs, bars at origin equal one standard error of the mean and are based on the pooled error of sample periods 10 to 32 ;

for $B$, bars from left to right indicate dry, moderate, and wet sites.

Quantité des radicelles vivantes $(A)$ et mortes $(B) \quad(<$ à $1 \mathrm{~mm}$ de diamètre) dans les premiers $75 \mathrm{~cm}$ du sol pendant la période de l'étude.

Pour les deux graphiques, les barres noires verticales à l'origine indiquent

l'erreur standard de la moyenne, et se basent sur l'erreur standard combinée des périodes d'échantillonnage 10 à 32; pour $B$, les barres se succédant de gauche à droite sont relatives respectivement aux stations sèches, frâ̂ches et mouillées. 
risons of means revealed that changes which were significant at 95 percent could occur within intervals as short as 1 month, but that the most convincing changes developed over intervals of 3 months or more. For changes from one month to the next to be significant at 95 percent, they must be greater than $3.33,2.52$, and $1.83 \mathrm{Mg} / \mathrm{ha}$ on the dry, moderate, and wet sites, respectively. For 3 -month intervals, changes in dead fine roots must be greater than $4.37,3.31$, and $2.39 \mathrm{Mg} / \mathrm{ha}$, and for 6 -month intervals, greater than $5.02,3.80$, and $2.75 \mathrm{Mg} /$ ha, respectively.

Long-term trends were similar for all three sites. Standing crops of dead fine roots remained unchanged, as on the dry site, or decreased to low levels until early to late summer 1978, when they increased through fall and winter to levels that were statistically significant on all sites. Overall levels of dead fine roots clearly differ by site; they were highest on the dry site and lowest on the wet site.

Seasonal changes of live and dead small roots were either nonexistent or obscured by the variation associated with these estimates (fig. $3 \mathrm{~A}$ and $3 \mathrm{~B}$ ). The long-term trend for live small roots on all three sites was downward by 1 to $2 \mathrm{Mg} /$ ha, while

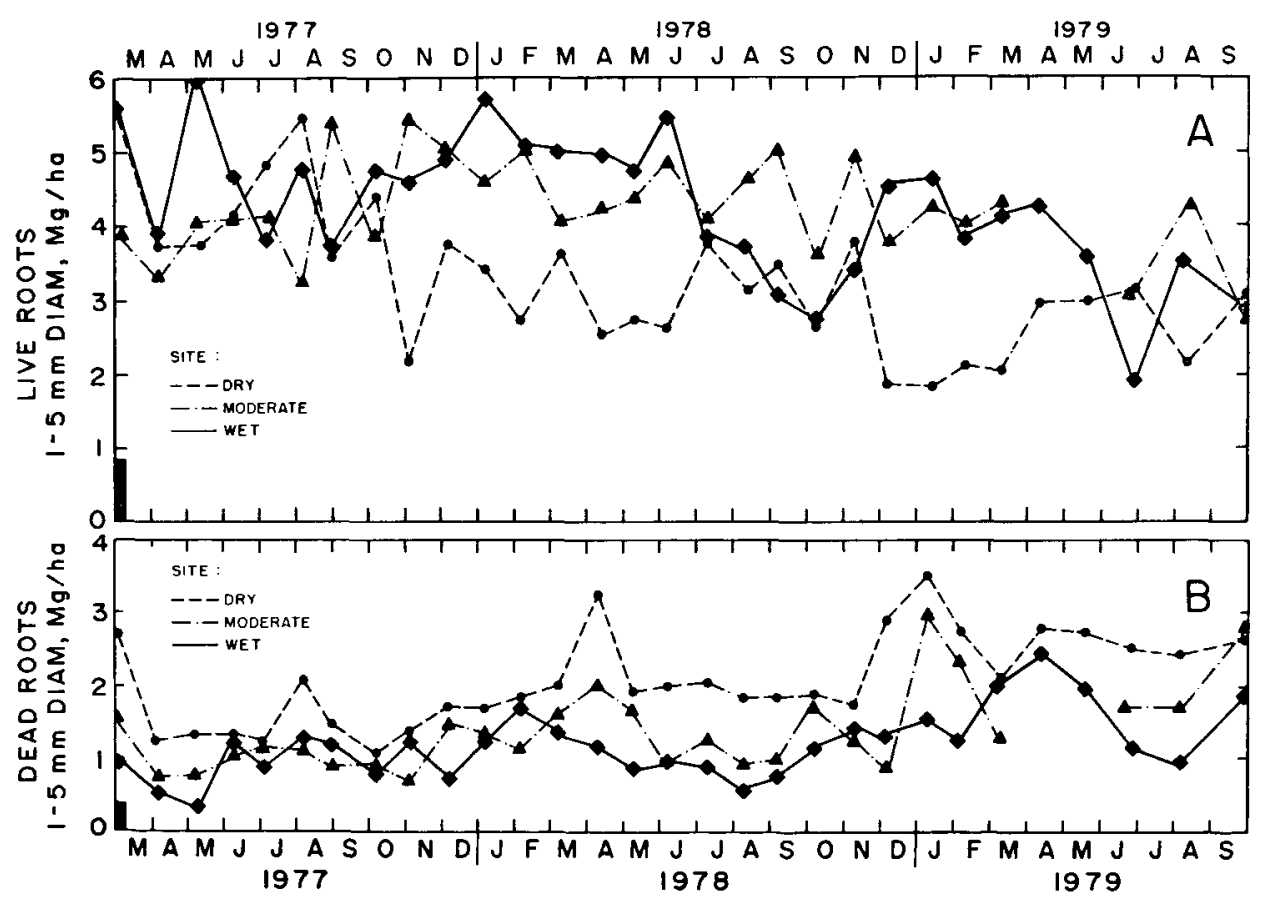

FIG. 3

Standing crops of live small (A) and dead small (B) roots in the upper $75 \mathrm{~cm}$ of soil during the study period. For both graphs, bars at origin equal one standard error of the mean and are based on the pooled error of sample periods 10 to 32.

Quantité de petites racines vivantes (A) et mortes (B) (de 1 à $5 \mathrm{~mm}$ de diamètre) dans les premiers $75 \mathrm{~cm}$ du sol pendant la période de l'étude.

Pour les deux graphiques, les barres noires verticales à l'origine indiquent

l'erreur standard de la moyenne, et se basent sur l'erreur standard combinée pour les périodes d'échantillonnage 10 à 32. 
dead small roots increased over this same period by a similar amount. As with dead fine roots, the highest standing crops of dead small roots were found on the dry site.

Overall standing crops of roots $<1$ and 1 to $5 \mathrm{~mm}$ diameter (tabl. 3) did not differ by site at probabilities exceeding 86 percent, except for dead fine roots. Standing crop of dead fine roots was 2.5 times greater on the dry site than on the wet, a difference which was significant at 99 percent confidence. Dead fine roots on the wet site also differed from those on the moderate at 99 percent confidence.

Fine roots, and to a lesser degree small roots, were most abundant in the uppermost layer of soil and decreased rapidly with increasing depth. The proportions of roots $<1$ and 1 to $5 \mathrm{~mm}$ in diameter in the upper $25 \mathrm{~cm}$ of soil were 70 percent and 50 percent, respectively, of the amounts found in the upper $75 \mathrm{~cm}$. We found a greater percentage of live fine roots in the litter layer of the wet site than in that of the dry site.
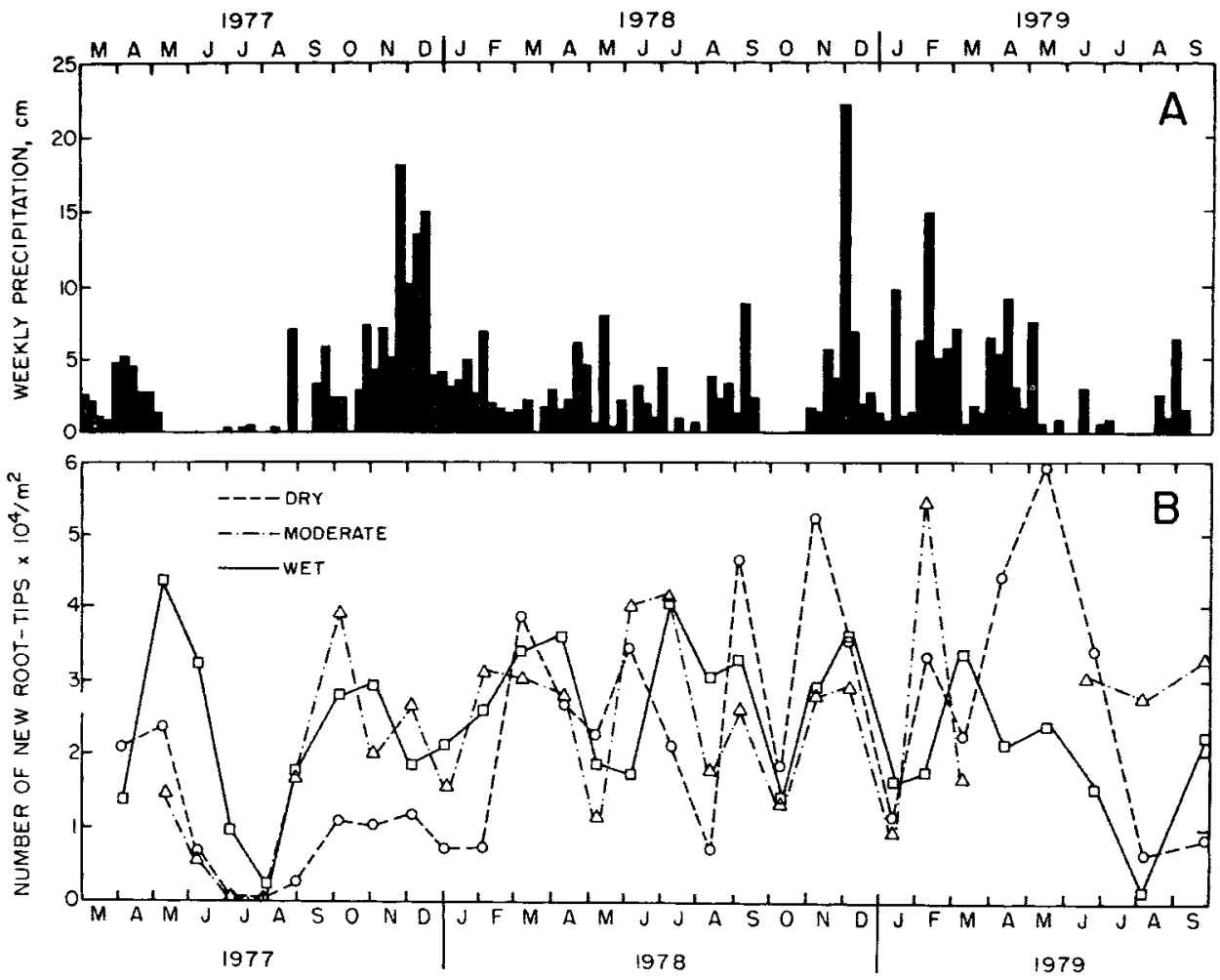

FIG. 4

Weekly precipitation (A) and number of new root-tips in upper $75 \mathrm{~cm}$ of soil (B) during the study period.

Précipitations hebdomadaires $(A)$ et nombre de nouvelles extrémités de racines dans les premiers $75 \mathrm{~cm}$ du sol (B) durant la période de l'étude. 


\subsection{Root-tip activity}

Changes in root-tip activity can be generally explained by seasonal changes in rainfall (fig. 4) and soil temperature. Increases in counts coincided with rainfall after droughty periods or when the soil warmed in spring, and decreases coincided with droughty periods in summer and fall or with low soil temperature in winter, though low counts in spring 1978 cannot be explained in this way. Except for brief interruptions caused by summer drought, root-tips remained active throughout the year. A comparison among the three sites revealed consistent tendencies toward cyclical bloomings of new root tips, especially in 1978 when considerable rainfall occurred during the growing season. A comparison from one year to the next did not reveal recurrent patterns except for peaks in the spring and fall of years with typically dry summers (1977 and 1979). Changes in root-tip activity did not necessarily correspond with changes in standing crop of fine roots. As with live fine roots, new root-tips were concentrated close to the surface. Activity, however, was greater in the litter layer of the wet site than in that of the dry site. With rare exceptions, root-tips of Douglas-fir were ectomycorrhizal. Because of the large variation in counts, we did not subject these data to statistical analyses.

\subsection{Fine-root production and turnover}

We calculated estimates of fine-root production and turnover for successive annual periods beginning in March and in September and mean annual estimates for the entire study period (tabl. 4). The relation of individual annual estimates to environmental conditions within sites indicated that higher rates of production and turnover were estimated for the year which includes the unusually cold winter of 1978-1979. The effect of severity of moisture stress appeared to differ by site : on the wet and moderate sites, annual rates of production and turnover were higher when summer moisture stress was higher; on the dry site, however, production declined slightly and turnover remained unchanged. The rate of decomposition was highest for all sites in the year when the relatively dry summer of 1977 was followed by the mild winter of 1977-1978. We did not sample long enough to quantify the effect of yearto-year changes in environmental conditions on annual rates of fine-root production, turnover, and decomposition. We have therefore reported estimates averaged over the entire period of the study. They equal $6.5,6.3$, and $4.8 \mathrm{Mg} / \mathrm{ha} /$ year for production, 7.2, 7.2, and $5.5 \mathrm{Mg} / \mathrm{ha} /$ year for turnover, and $8.2,8.0$, and $6.9 \mathrm{Mg} / \mathrm{ha} /$ year for decomposition on the dry, moderate, and wet sites, respectively. Mean annual estimates indicate that fine-root production and turnover were 30 to 40 percent greater on the dry than on the wet site.

We calculated a turnover index to compare rates of turnover and mean standing crop of fine roots among sites (tabl. 4). Over the course of the study, the index was highest for the dry site (2.8), intermediate for the moderate site (2.0), and lowest for the wet site (1.7). When we computed the turnover index for annual periods, the ranking among sites remained the same, despite large differences in estimates from one year to the next. Whereas rates of production and turnover were only 30 to 40 percent greater on the dry than on the wet site, the turnover index indicated a greater difference between these sites : it was 65 percent higher on the dry site. 
TABLE 4

Estimates of fine-root production, turnover, and decomposition in the upper $75 \mathrm{~cm}$ of soil. Turnover index indicates number of times mean standing crops of fine roots were replaced ench year.

Estimations de la production de radicelles, de leur rotation et de lear décomposition dans les premiers $75 \mathrm{~cm}$ du sol.

L'index de rotation indique le nombre annuel de remplacement de quantités moyennes de radicelles pour chaque année.

\begin{tabular}{|c|c|c|c|c|c|c|}
\hline \multirow{2}{*}{$\begin{array}{c}\text { Site } \\
\text { and } \\
\text { annual period }\end{array}$} & \multicolumn{2}{|c|}{$\begin{array}{l}\text { Environmental } \\
\text { conditions }\end{array}$} & \multirow{2}{*}{$\begin{array}{c}\text { Production } \\
(\mathrm{Mg} / \text { ha/year })\end{array}$} & \multirow{2}{*}{$\begin{array}{c}\text { Turnover } \\
\mathrm{Mg} / \mathrm{ha} / \text { year) }\end{array}$} & \multirow{2}{*}{$\begin{array}{c}\text { Turnover } \\
\text { index* } \\
\text { (times/ycar) }\end{array}$} & \multirow{2}{*}{$\begin{array}{c}\text { De- } \\
\text { composition } \\
\text { (Mg/ha/year) }\end{array}$} \\
\hline & Summer & Winter & & & & \\
\hline \multicolumn{7}{|l|}{ Dry } \\
\hline Mar. 77-Mar. 78 & Dry & Mild & 4.5 & 5.6 & 1.8 & 10.0 \\
\hline Mar. 78-Mar. 79 & Wet & Cold & 8.5 & 8.6 & 4.0 & 7.6 \\
\hline Sep. 77-Sep. 78 & Wet & Mild & 5.2 & 5.6 & 2.2 & 5.6 \\
\hline \multirow[t]{2}{*}{ Sep. 78-Sep. 79} & Dry & Cold & 7.9 & 8.6 & 5.2 & 8.0 \\
\hline & \multicolumn{2}{|c|}{ Mean of study } & 6.5 & 7.2 & 2.8 & 8.2 \\
\hline \multicolumn{7}{|l|}{ Moderate } \\
\hline Mar. 77-Mar. 78 & Dry & Mild & 5.8 & 6.9 & 1.6 & 9.1 \\
\hline Mar. 78-Mar. 79 & Wet & Cold & 8.6 & 8.7 & 2.8 & 7.2 \\
\hline \multirow{3}{*}{$\begin{array}{l}\text { Sep. } 77 \text {-Sep. } 78 \\
\text { Sep. } 78 \text {-Sep. } 79\end{array}$} & Wet & Mild & 2.8 & 4.2 & 1.2 & 7.2 \\
\hline & Dry & Cold & 9.0 & 10.3 & 5.0 & 7.5 \\
\hline & \multicolumn{2}{|c|}{ Mean of study } & 6.3 & 7.2 & 2.0 & 8.0 \\
\hline \multicolumn{7}{|l|}{ Wet } \\
\hline Mar. 77-Mar. 78 & Dry & Mild & 4.4 & 5.3 & 1.3 & 8.2 \\
\hline Mar. 78-Mar. 79 & Wet & Cold & 6.3 & 6.5 & 2.5 & 5.4 \\
\hline \multirow{3}{*}{$\begin{array}{l}\text { Sep. } 77-\text { Sep. } 78 \\
\text { Sep. } 78-\text { Sep. } 79\end{array}$} & Wet & Mild & 2.8 & 3.9 & 1.2 & 7.1 \\
\hline & Dry & Cold & 6.5 & 7.1 & 3.5 & 5.6 \\
\hline & \multicolumn{2}{|c|}{ Mean of study } & 4.8 & 5.5 & 1.7 & 6.9 \\
\hline \multirow{2}{*}{ * Turnover in } & \multicolumn{4}{|c|}{ Turnover (Mg/ha/year) } & & \\
\hline & \multicolumn{4}{|c|}{ Mean standing crop of fine roots $(\mathrm{Mg} / \mathrm{ha})$} & & \\
\hline
\end{tabular}




\section{Discussion}

\subsection{Production and turnover of fine roots}

Soil cores or small soil monoliths are currently the most reliable method of estimating standing crops of fine roots in forests, especially when repeated estimates are made within the same stand (Roberts, 1976 ; Harris et al., 1980 ; Persson, 1983). Production and turnover of fine roots have usually been estimated from changes in standing crop. The most appropriate way to make such calculations, however, remains unresolved (McClaugherty et al., 1982 ; Fogel, 1983 ; Persson, 1983). Nevertheless, technical problems are generally limited to sampling and sorting out roots; reasonable levels of precision can be achieved with relatively small sample sizes (KoHMANN, 1972). Sample processing, however, is very labor-intensive, and usually some compromise must be made between frequency and intensity of sampling. Other methods which have been used to estimate fine-root production in forests include measuring growth of roots into artificially created root-free areas (McGinTY, 1976 ; Persson, 1979, $1980 \mathrm{~b}$; JoRdan \& EsCalante, 1980 ; MCClaugherty et al., 1982), extrapolation of measurements of root growth from observation windows (KEYEs \& GRIER, 1981), and use of radioactive tracers (WALLER \& OLSON, 1967). Possible artifacts of these approaches, however, have not been adequately defined and quantified.

Santantonio (1979) developed a method of calculating annual rates of production and turnover which was consistent with the concept that fine-roots are a dynamic component of temperate forest ecosystems. REYNOLDS (1970, 1975) suggested that cycles of growth and shedding of fine roots occur in cells as small as $30 \mathrm{~cm}$ in diameter, and that at any one time different microsites are not in synchrony, but in different phases. Thus, recognizing the importance of accounting for fine-root mortality when developing such estimates, we incorporated changes in dead fine roots into our scheme of estimation. Others have also done so (Persson, 1978, 1979, 1980 a ; Keyes \& Grier, 1981; MCClaugherty et al., 1982). Becalıse we knew so little about fine-root growth of Douglas-fir in mature stands, we developed equations which require few initial assumptions. We made no assumptions regarding the behavior of fine-root growth. If fine-root production is estimated from changes in live fine roots alone and dead fine roots are not accounted for, then it must be assumed that growth and death of fine roots do not occur simultaneously.

We made the following assumptions for the purpose of estimating fine-root production, turnover, and decomposition :

- theoretically, estimates based on changes in standing crops of live and dead fine roots are underestimates;

- major changes in standing crops can be estimated by monthly samples;

- sample period means are unbiased estimators of population means;

- pooled errors from the one-way analysis of variance are estimates of population variances;

- live and dead roots can be consistently distinguished at a reasonable level of resolution;

- fine-root decomposition can be estimated as the rate that dead fine roots disintegrate. 
Relatively high levels of precision associated with means, good agreement between duplicate samples, and generally consistent seasonal patterns among sites increased our confidence in the data as a basis for estimating fine-root production and turnover. Sampling monthly generally appeared adequate, but there were several times when biweekly sampling would have been necessary to provide a satisfactory definition of changes in standing crop. Although statistically significant, some relative highs and lows were indicated by only a single data point. Because the effort needed for sampling was relatively low, extra sampling periods could be added and the samples stored and then processed if intermediate points were needed.

The equations we developed are similar to those of Persson (1978, 1979, 1980 a). His equations, however, do not adequately account for production and turnover under certain situations. They underestimate production when an increase in live fine roots occurs at the same time as a decrease in dead fine roots, and they underestimate turnover when the decrease in live fine roots exceeds the increase in dead fine roots. Both methods adjust for overestimation which results from random variation in periodic estimates by subtracting a correction factor. Both have the advantage of estimating finc-reot production and turnover directly without the need to assume that the two are in equilibrium on an annual basis.

Our estimates of fine-root production are within the range of values reported for Douglas-fir and for other temperate forests (tabl. 5). They indicate that standing crops of fine roots were replaced an average of 1.7 to 2.8 times per year, depending on site. When compared to foliage litterfall in these stands for the same years (SANTANTONIO, 1982), fine-root turnover exceeded that of foliage by a factor of 2.5 to 4.2 , depending on site. Persson (1978), Fogel \& Hunt (1979), Harris et al. (1980), and GrIER et al. (1981) have reported similar findings for stands of Scots pine, Douglas-fir, yellow-poplar, and subalpine fir, respectively. Thus, available evidence from temperate forests strongly supports the contention that the greatest input of organic matter to the soil ecosystem comes through fine-root turnover (Coliman, 1976; Harris et al., 1980).

No other comparably developed estimates of fine-root decomposition are available for comparison. Perhaps the closest is that of McGinty (1976), who reported $>50$ percent annual decline in the dry weight of roots $<25 \mathrm{~mm}$ in diameter in a mixed oak stand in North Carolina. He used an in situ technique which causes minimal disturbance : 120 open aluminum tubes were driven into the soil to a $30-\mathrm{cm}$ depth; 20 of these were removed immediately and the roots extracted; the remaining tubes were recovered at 3 -month intervals, 20 each time, for 1 year. Loss in biomass was assumed to equal decomposition. Inasmuch as his estimate includes small and large roots, the decomposition rate of roots $<1 \mathrm{~mm}$ in diameter was probably much greater than that of the size class as a whole (HARRIS et al., 1980). Further evidence of the rapid disappearance of fine roots has been discussed by KolesNikov (1968), WAID (1974) and LYFORD (1975).

We should point out that estimates developed by placing roots $<5 \mathrm{~mm}$ in diameter in litter bags and recording the loss of dry weight with time disagree with our findings. Such estimates indicate that annual losses in dry weight amount as $<30$ percent (Fogel \& Hunt, 1979 ; Berg, 1981; McClaugherty et al., 1982); they are an order of magnitude lower than our findings. This large discrepancy may arise, in part, from the treatment, condition, and size of roots placed in litter bags. We would expect larger, woody, vigorous roots which have been washed, dried, and 
placed in nylon mesh bags to decompose much more slowly than the succulent, nutrient-rich, root-tips in situ which made up to greatest proportion of our annual fineroot turnover.

Several factors contribute to making our estimates conservative. First, unknown amounts of production and turnover occurred between monthly sampling periods and were not reflected in estimates of standing crops. Because the longevity of fine roots of trees may be as short as several days (LYR \& HofFManN, 1967; Lyford, 1975 ; Hermann, 1977 ; Keyes \& Grier, 1981), somes fine roots are likely to have grown, died, and disintegrated between sample periods. We also made no attempt to estimate losses to grazers. Although few data exist, such losses have been estimated at $<10$ percent (Ausmus et al., 1978 ; Harris et al., 1980 ; Magnusson \& SCHLENIUS, 1980). Second, our method does not account for production that occurred as radial growth of fine roots out of the $<1$-mm-diameter size class. Third, the amount of roots in individual samples was underestimated because reductions in dry weight of live fine roots probably occurred as a result of physiological respiration during sample processing and because some fragments of dead root-tips passed through the 800 -micron mesh sieve and were not considered in our estimates.

Variations in climate over a period of a few years can have a significant impact on root system morphogenesis (SUTTON, 1980). Annual estimates within the same site indicate that fine-root production and turnover may vary substantially from one year to the next and that these variations may exceed those between sites in the same year. We have not reported standard errors for annual estimates of fine-root dynamics because we currently lack a method to estimate the precision of these rates. It is unlikely that all differences among annual rates are significant for all sites and years. We therefore recommend using the mean annual estimates for general comparisons, as they are likely to be more representative of gencral conditions.

Environmental conditions varied considerably during the course of the study. This variation created some unexpected opportunities to observe fine-root growth over a much broader range of environmental conditions within site. The price, however, was high : successive years could not serve for replication of annual cycles as we had intended. These condtions enabled us to observe fine-root growth in the absence of summer moisture stress and when winter soil temperatures were lower than commonly found in the subalpine zone. The relatively extreme effect of soil freezing appeared to affect fine root production and turnover more than changes in moisture stress on these sites.

\subsection{Statistical analyses of sample means}

Although large seasonal fluctuations in roots have been commonly observed, large standard errors give cause to question whether such changes were « real» or merely an artifact of variation. Most researchers have not reported statistical tests of their data. We did not attempt to test data of other investigators because insufficient information was reported for a posteriori multiple range tests of sample period means. The simple t-test and least significant difference (LSD) have been used to test for differences between these means, but authors have not stated when specific tests were planned or whether multiple range comparisons were performed. We must point out that the simple Student's t-test and the LSD are generally inappropriate for multiple range comparisons or a posteriori testing of means. If so used, the probability of 


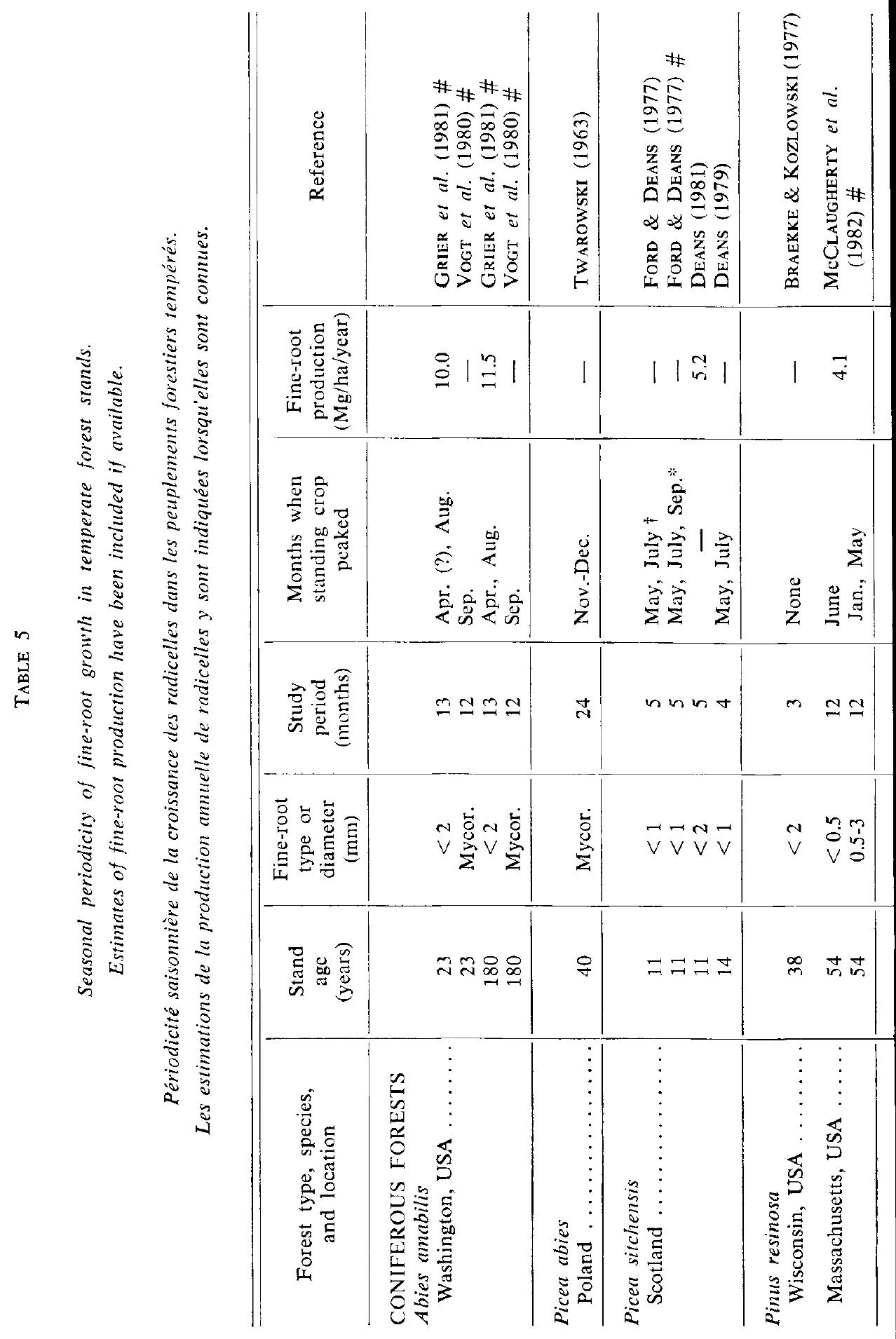




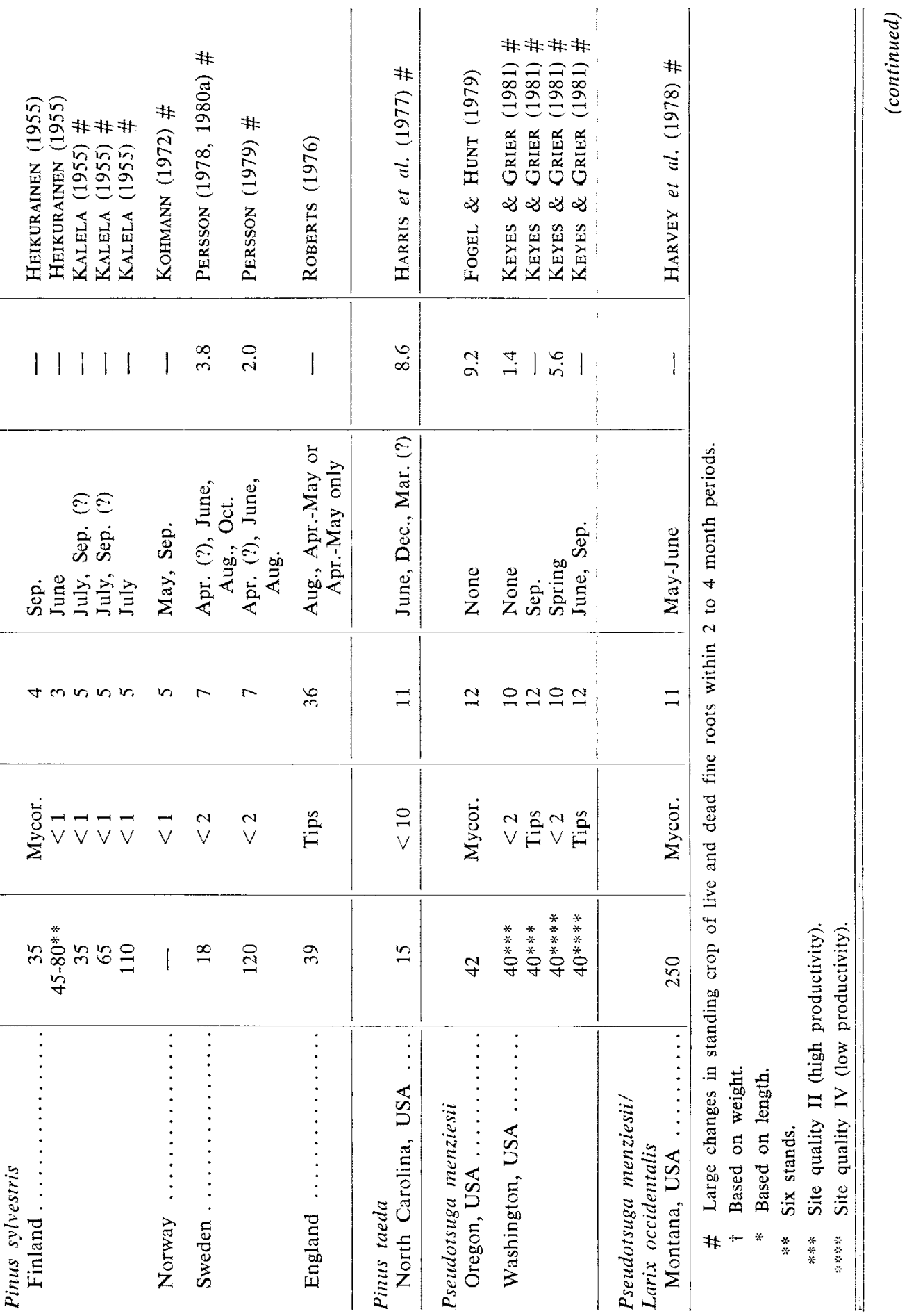




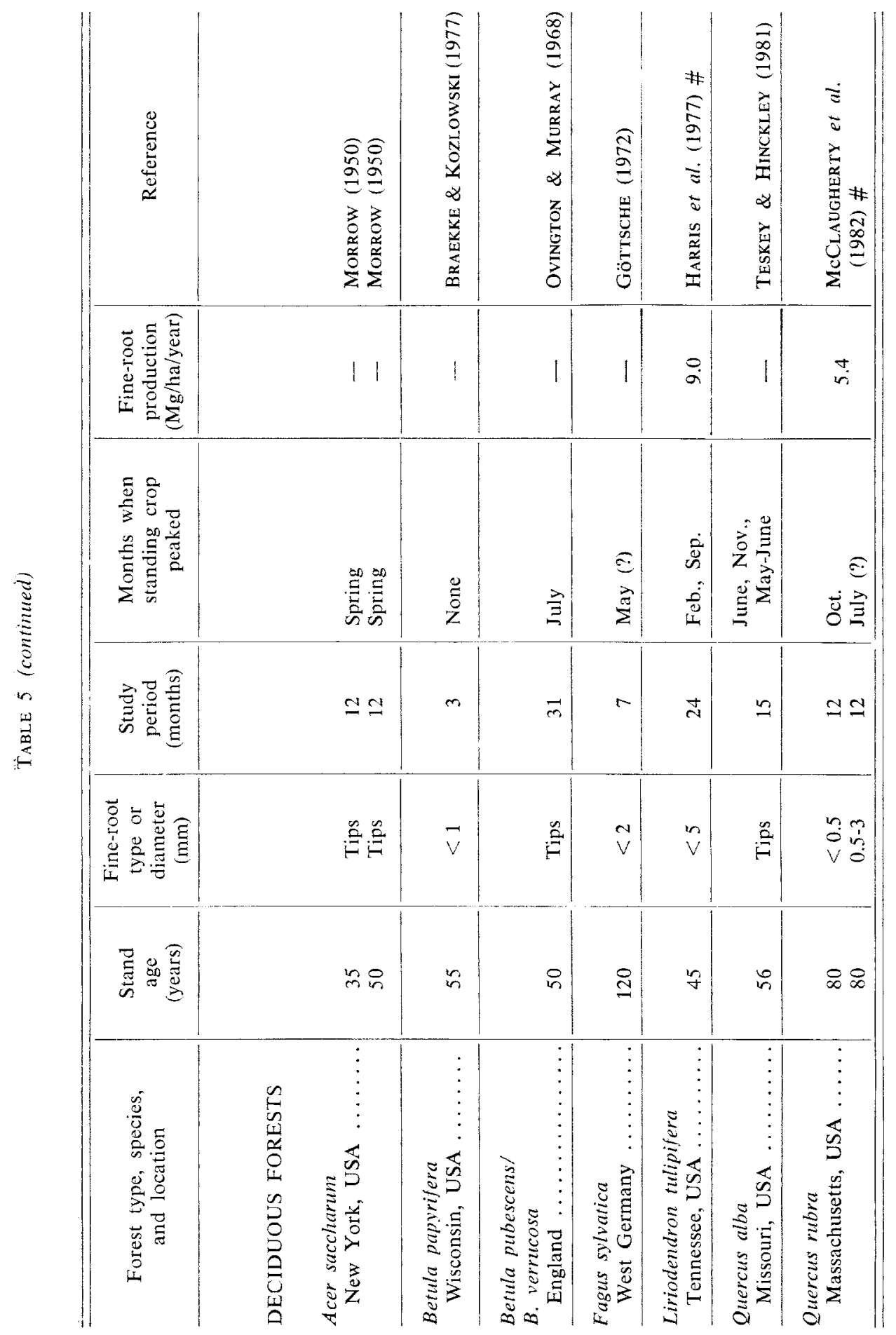


making a Type 1 Error (accepting a false hypothesis) increases, especially as more comparisons are made (Sokal \& Rohif, 1969 ; Neter \& Wasserman, 1974 ; Steel. \& TORrIE, 1980). Tests between minimum and maximum values usually end up as a posteriori tests, unless investigators select exactly which pairs of means will be tested before they see the data.

\subsection{Periodicity of fine-root growth}

Differences in methods, in frequency of sampling, and in size of roots considered create difficulties for comparing results of other studies directly (FogEL, 1983; Persson, 1983). We sought to minimize the effects of such differences by comparing seasonal fluctuations in growth activity or standing crop as proportional changes over 2- to 4-month intervals. We found large changes in fine roots for many coniferous and deciduous species. Studies in wich increases exceeded 100 percent and decreases exceeded 50 percent within a 2 - to 4 -month period have been noted with the code «\# in table 5. Of the limited data on standing crops of dead fine roots, those of Keyes \& Grier (1981) and Persson (1978, 1979) show this amount of fluctuation; data of McClaugherty et al. (1982), however, do not. Thus, fine roots of other temperate forests apparently undergo large seasonal fluctuations in growth activity or standing crop on the order of those observed in our study.

Changes in root-tip activity do not always correspond to changes in standing crop of fine roots. This was particularly evident in our study during most of 1978, which was the relatively wet growing season. Data of Heikurainen (1955), VogT et al. (1980), Keyes \& Grier (1981), and MCClaugherty et al. (1982) also show discrepancies between changes in standing crop and activity of root-tips and may indicate simultaneous cycles of production and turnover. Incidentally, changes on the basis of weight may not correspond to those on the basis of length (Ford \& DEANS, 1977), and periods of maximum elongation may not correspond with those of fineroot ramification (TESKEY \& HINCKLEY, 1981).

We found wide variation in the number and timing of intervals of pcak fine-root growth for both coniferous and deciduous forest (tabl. 5). One or two major periods of growth were most commonly observed. When one peak was observed, the maximum amount of fine-root growth occurred during spring or summer, although MC-CLAUGHERTY et al. (1982) found that roots $<0.5 \mathrm{~mm}$ in diameter peaked during fall in a red oak stand. When two peaks were observed, the first peak occurred in spring and a second, but not necessarily lower, peak in late summer or fall. For a yellow-poplar stand in Tennessee, however, Harris et al. (1977) found that the first peak occurred in late winter during two consecutive years. In some conifer stands, three or more peaks were observed (Ford \& Deans, 1977; Harris et al., 1977 ; Persson, 1978, 1979). In many studics, sampling was not conducted throughout the entire year; thus, all periods of fine-root growth may not have been sampled.

Data from successive years in the same stand are available from only a few sources. Although HARris et al. (1977) and GrIER et al. (1982) generally found similar seasonal patterns for yellow-poplar and subalpine fir in consecutive years, recurring patterns were lacking in other studies. Differences in the number, magnitude, or timing of peaks for successive years were observed for beech (GöTTSCHE, 1972), brch (Ovington \& Murray, 1968), Scots pine (Heikurainen, 1955 ; Roberts, 1976), and for Douglas-fir in this study. 
Forests of Douglas-fir in the U.S. Pacific Northwest and Scots pine in northern Europe have been studied most extensively. They represent relatively localized areas and present the best opportunity for examining the variability in seasonality of fine-root growth. In six stands of Douglas-fir (including those of this study), patterns of fine-root growth varied from none to three peaks per year. High levels of fine-root growth occurred as early as February and continued as late as November. In nine stands of Scots pine forests, patterns varied from one to four peaks per year ; fineroot growth peaked as early as April and as late as October. Root growth was not limited to the growing season of the shoot. This pattern is also indicated by the results for many other species listed in table 5. There appears to be as much variation within species as between them, a possibility suggested by our previous comparisons of whole root systems (Santantonio et al., 1977). Further evidence of the extensive period and variability of root growth when compared to shoot growth of temperate forest trees has been discussed by LYR \& HofFMANN (1967), HofFManN (1972), and RiEDACKER (1976). The impact of site conditions, therefore, must substantially modify endogenous control of root growth.

Attempts to correlate growth dynamics of fine roots in forests with environmental conditions, however, have yielded inconclusive results. Low soil temperature and low soil moisture are widely recognized as adversely affecting root growth, with the first generally limiting growth in winter and the second in summer (LYR \& HoFFMANN, 1967 ; HermanN, 1977; Russell, 1977). Changes in standing crops of fine roots of Douglas-fir in our study generally reflected changes in environmental conditions. In most of the studies listed in table 5, investigators related changes in standing crop or growth activity of fine roots to overall changes in site conditions with varying degrees of success. The effect of low soil temperature consistently resulted in low levels of root growth during winter, but the effect of low soil moisture was not so clear. KonmanN (1972) found in a drying experiment that as long as part of the root system had access to water, water balance of roots exposed to drying was maintained.

In only a few studies did the investigators directly evaluate root activity and specific environmental conditions simultaneously. RobERTs (1976), using multivariate analysis, was unable to establish significant correlations of root activity to moisture and tempcrature in various soil horizons. He observed the highest level of root activity during late August despite low levels of soil water, although this August peak was completely absent in the succeeding two years of the study. Deans (1979), on the other hand, has reported a seasonal influence of soil temperature and moisture on the rate of fine-root growth : as soil temperature increased, root growth increased, but this relation was overridden and halted by low soil moisture later in the season. Appreciable losses of fine roots, however, coincided with the onset of shoot elongation before water availability declined. TESKEY \& Hinckley (1981) found that the rate of root elongation increased as environmental conditions became more favorable but that the number of growing roots and the projected rate of biomass accumulation increased at cool soil temperatures and at low soil water potentials.

Although the direct effects of soil temperature and moisture explain many aspects of finc-root growth, they alone do not provide an adequate basis for predicting the seasonal pattern in temperate forests. Nor can this pattern be predicted on the basis of shoot growth. In addition to the environment of root and shoot, many factors affect root growth. They include growth-regulatory substances, carbohydrate availability, nutrient status, respiration rates, relations with symbionts, and competitive rela- 
tions (Lyr \& Hoffmann, 1967; Sutton, 1969, 1980 ; Troughton, 1974 ; RiEDaCKer, 1976 ; Russell, 1977 ; Caldwell, 1979 ; Persson, 1983). Manipulations of the shoot, such as pruning, defoliation, and shading, affect root growth (RICHARDSON, 1968 ; Head, 1973 ; Perry, 1982). Thus, available evidence indicates that root and shoot growth in forests are closely interrelated but are controlled by a complex interaction of endogenous and exogenous factors.

The relationship between standing crops of live and dead fine roots is difficult to explain but probably reflects effects of various environmental conditions on the allocation of resources to fine roots and on their decomposition when they die. Although the carbon pools are linked directly, we have been unable to determine any consistent relationship between changes in the two. Within site, we found corresponding changes (both increasing or both decreasing), as well as opposing ones (one increasing and the other decreasing). Corresponding increases presumably indicate coincidence of processes causing production and turnover of fine roots. Data of MCCLAUGHERTY et al. (1982) similarly indicate that the relationship between the two standing crops can change during the year. Other investigators, however, have reported data that show more consistent patterns within site. Persson (1978) found corresponding changes in a 18-year-old stand of Scots pine, but he found opposing changes in a 120-year-old stand (Persson, 1979). Keyes \& Grier (1981) also found opposing changes in a Douglas-fir stand of low productivity aged 40 years.

We were unable to sample long enough to determine periodicities of long-term patterns. Our results, however, are the first to suggest the possibility of long-term cycles in small- and fine-root growth. It should be borne in mind, nevertheless, that other factors may explain these results :

- Unusual climatic conditions such as the drought in the winter of 1976-1977, followed by the relatively wet growing season of 1978 and soil freezing during the winter of 1978-1979 may have created a deviation from what are usually consistent overall levels of standing crops.

- The supposed cycles may be an artifact of our methods. In regard to the latter, we did, however, take care to develop procedures which could be repeated each month in a consistent manner. Close supervision of workers and checks of samples were intended to maintain consistent processing throughout the study. Although we do not believe these indications of long-term cycles are artifacts, we cannot rule out such a possibility. Neither can we explain why these roots might undergo such cycles, but we do suggest that changes in carbohydrate or nutrient status may regulate the levels of standing crops than can be maintained from one year to the next. It may be only a coincidence, but 1978 was the best cone collection year in that area since 1972 (personal communication, V. Puleo, H.J. Andrews Experimental Forest). We might speculate that a connection between root and cone growth exists as a result of changes in allocation of carbohydrates or nutrients.

\subsection{Concluding remarks}

Results of the present study contribute a few more pieces to the puzzle of how root system function in temperate forests. As described in the introduction, the greater standing crop of fine and small roots of Douglas-fir in the dry than in the wet habitat of Watershed 10 probably resulted from a much larger component of 
dead fine roots in the former. Standing crops of fine roots changed seasonally and generally reflected changes in environmental conditions. Except for brief interruptions, fine roots remained active throughout the year and recovered quickly from adverse environmental conditions. Douglas-fir on the dry site did not maintain a larger fineroot system than on the wet site, but it may have exploited a greater volume of soil through greater growth and replacement of fine roots in a succession of microsites. Reynolds (1975), Caldweli (1979), and Harris et al. (1980) have discussed similar adaptive strategies of fine roots. If one considers the amount of photosynthate that is needed to sustain this high level of activity, then one must conclude that fine-root function constitutes a major pathway of carbon cycling in temperate forests.

We propose that growth of roots differs fundamentally from that of shoots by being far more opportunistic and exploitative. Perhaps this is possible because roots live in a less severe environment. Cyclic death and replacement of ephemeral fine roots in a succession of favorable microsites may be an adaptive strategy for maintaining the largest number of active fine roots at a minimum metabolic cost. What we observe as seasonal changes of fine roots represents the outcome of an interplay of complex processes within an economy of limited resources.

\title{
Acknowledgements
}

Wc thank D. Chojnacky, E. Depree, and those who processed soil core samples for their valuable technical assistance. G. Santantonio of the California Institute of Technology improved the design of the soil coring device. We acknowledge the cooperation of the Forest Research Laboratory, the H.J. Andrews Experimental Ecological Reserve, and the Blue River and McKenzie Districts of the Willamette National Forest.

This research was supported by grants DEB 76-21403 and DEB 79-06042 from the Ecosystems Studies Program of the National Science Foundation. This is paper No. 1695 of the Forest Research Laboratory, Oregon State University. Computerized raw data and supporting documcntation are available from Oregon State University's Forest Science Data Bank.

\author{
Résumé \\ Biomasse, production et évolution des fines racines de douglas, \\ en stations sèche, fraîche et humide dans l'ouest de l'Oregon
}

Les autcurs ont prélevé des échantillons de quantités de radicelles $(<1 \mathrm{~mm}$ de diamètrc) et de petites racines $(1-5 \mathrm{~mm}$ de diamètre) vivantes et mortes dans les premiers $75 \mathrm{~cm}$ du sol dans les stations sèches, fraîches et mouillées de peuplements de douglas (Pseudotsuga menziesii) arrivés à maturité pendant la période de mars 1977 à septembre 1979. Pendant cette période, de grands changements, statistiquement significatifs, dans les quantités de radicelles ont eu lieu en peu temps $1<3$ mois). En général, la quantité de petites racines ne changeait pas de façon statistiquement significative et importante. La quantité de radicelles vivantes $(2,5$ à $3,5 \mathrm{Mg} / \mathrm{ha})$ ne diffèrait pas statistiquement de station à station ; par contre, la quantité des radicelles mortes diffèrait fortement $(10,7 \mathrm{Mg} / \mathrm{ha}$ pour la station sèche; $4,1 \mathrm{Mg} / \mathrm{ha}$ pour la station mouillée).

A partir des changements intervenant dans la quantité de radicelles vivantes et mortes, nous avons pu estimer la production de radicelles dans les stations respectivement sèches, 
fraîches et mouillées à $6,5,6,3$ et $4,5 \mathrm{Mg} / \mathrm{ha} / \mathrm{an}$; la rotation à $7,2,7,2$ et $5,5 \mathrm{Mg} / \mathrm{ha} / \mathrm{an}$; et la décomposition des racines mortes à $8,2,8,0$ et $6,9 \mathrm{Mg} / \mathrm{ha} / \mathrm{an}$. L'effet des conditions de station est caractérisé par le nombre de fois par an que la quantité moyenne de radicelles vivantes est retournée au sol : 2,8 en station sèche, 2,0 en station fraîche et 1,7 en station mouillée. La mort cyclique et le remplacement des radicelles dans une succession de microstations favorables suggèrent une stratégie adaptative pour maintenir le plus grand nombre de racines actives avec le minimum de dépense métabolique. Les résultats de cette étude confirment le rôle important joué par les radicelles dans le recyclage de carbone en forêts tempérées : elles en constituent une des voies principales.

\section{References}

Agren G.I., Axelsson B., Flower-Ellis J.G.K., Linder S., Persson H., Staaf H., Troeng E., 1980. Annual carbon budget for a young Scots pine In : Structure and function of northern coniferous forests, 307-314, Persson T. Ed., Ecol. Bull. 32, Swedish Natural Science Research Council, Stockholm.

Ausmus B.S., Ferris J.M., Reichle D.E., Williams E.C., 1978. The role of belowground herbivores in mesic forest root dynamics. Pedobiologia, 18, 289-295.

BERG B., 1981. Litter decomposition studies within SWECON. Data on weight loss and organic chemical composition. Report 101, Swedish Coniferous Forest Project, Uppsala.

Braekke F.H., Kozlowski T.T., 1977. Distribution and growth of roots in Pinus resinosa and Betula papyrifera stands. Meddr Norsk Inst. Skogforsk., 33, 437-451.

Caldwell M.M., 1979. Root structure : The considerable cost of below-ground function. In : Topics in plant population biology, 408-427, Solbrig O. et al. Ed., Columbia University Press, New York.

COLEMAN D.C., 1976. A review of root production processes and their influence on soil biota in terrestrial ecosystems. In : The role of terrestrial and aquatic organisms in decomposition processes, 417-434, Anderson A. and Macfadyen A. Eds., Blackwell Scientific Publications, Ltd., Oxford.

DEANs J.D., 1979. Fluctuations of the soil environment and fine root growth in a young Sitka spruce plantation. Pl. Soil, 52, 195-208.

Denns J.D., 1981. Dynamics of coarse root production in a young plantation of Picea sitchensis: Forestry, 54, 139-155.

Dyrness C.T., Franklin J.F., Molr W.H., 1974, A preliminary classification of forest communities in the central portion of the western Cascades in Oregon. Bull. No. 4, Coniferous Forest Biome, University of Washington, Seattle, WA.

FAYI.E D.C.F., 1968. Radial growth in tree roots. Tech. Rep. No. 9, Faculty of Forestry, University of Toronto.

Foger. R., 1983. Root turnover and productivity of coniferous forests. Pl. Soil, 71, 75-85.

Fogel R., Hunt G., 1979. Fungal and arboreal biomass in a western Oregon Douglas-fir ecosystem : Distribution patterns and turnover. Can. J. Forest Res., 9, 245-256.

Ford E.D., Deans J.D., 1977. Growth of Sitka spruce plantation : Spatial distribution and seasonal fluctuations of lengths, weights and carbohydrate concentrations of fine roots. Pl. Soil, 47, 463-485.

Franklin J.F., Dyrness C.T., 1973. Natural vegetation of Oregon and Washington. Gen. Tech. Rep. PNW-8, USDA Forest Service, Pacific Northwest Forest and Range Experiment Station, Portland, OR.

Franklin J.F., Waring R.H., 1980. Distinctive features of the northern coniferous forest : Development, structure and function. In : Forests : Fresh perspectives from ecosystem analysis, 59-88, Waring R.H. Ed., Oregon State University Press, Corvallis, OR.

Gholz H.L., Grier C.C., Campbell A.G., Brown A.T., 1979. Equations for estimating biomass and leaf area of plants in the Pacific Northwest. Resp. Pap. 41, Forest Research Laboratory, Oregon State University, Corvallis, OR. 
Goltz S.M., Benort G., Schimmelpfennig H., 1981. New circuitry for measuring soil water matric potential with moisture blocks. Agric. Met., 24, 75-82.

GötrSCHE. D., 1972. Verteilung von Feinwurzeln und Mykorrhizen im Bodenprofil eines Buchen- und Fichtenbestandes im Solling. Mitt. BundForschA nst. Forst- . Holzw. No. 88, Hamburg.

Grier C.C., Logan R.S., 1977. Old-growth Pseudotsuga menziesii comunities of a western Oregon watershed : Biomass distribution and production budgets. Ecol. Monogr., 47, 373-400.

Grier C.C., Vogt K.A., Keyes M.R., Edmonds R.L., 1981. Biomass distribution and aboveand belowground production in young and mature Abies amabilis zone ecosystems of the Washington Cascades. Can. J. Forest Res., 11, 155-167.

Gril:R C.C., Vogt K.A., TESkey R.O., 1982. Carbon uptake and allocation in subalpine ecosystems. In : Carbon uptake and allocation in subalpine ecosystems as a key to management, pp. 64-69, Waring R.H. Ed., Proc. IUFRO Workshop. Forest Research Laboratory, Oregon State University, Corvallis, OR.

Harris W.F., Kintrsson R.S., Edwards N.T., 1977. Comparison of belowground biomass of natural deciduous forests and loblolly pine plantations. Pedobiologia, 17, 369-381.

HaRRIS W.F., Santantonio D., McGinty D., 1980. The dynamic belowground ecosystem. In : Forest : Fresh perspectives from ecosvstem analysis, pp. 119-129, Waring R.H. Ed., Oregon State University Press, Corvallis, OR.

Harvey A.E., Larsen M.J., Jurgensen M.F., 1978. Seasonal distribution of cctomycorrhizae in a mature Douglas-fir/larch forest soil in western Montana. Forest Sci., 24, 203-208.

HAWK G.M., 1979. Vegetation mapping and community description of a small western Cascade watershed. NW. Sci., 53, 200-212.

HEAD G.C., 1973. Shedding of roots. In : Shedding of plant parts, pp. 237-293, Kozlowski T.T. Ed., Academic Press, New York.

HeikURainen L., 1955. Ueber Veraenderungen in den Wurzelverhaeltnissen der Kiefernbestaende auf Moorboeden im Lauf des Jahres. Acta for. fenn., 65 (2), 1-54.

Hrilwig J., Council K., 1979. SAS user's guide. Statistical Analysis System Institute, Inc., Raleigh, NC.

HI:RMANN R.K., 1977. Growth and production of tree roots: A review. In : The belowgrom ecosystem : A synthesis of plant-associated processes, pp. 7-28, Marshall J.K. Ed., Range Sci. Dep. Sci. Ser. 26, Colorado State University, Fort Collins, CO.

Hofrmann G., 1972. Wachstumsrhythmik der Wurzeln und Sprossachsen von Forstgehoelzen. Flora, Jena, 161, 303-319.

Jordan C.F., Escalante G., 1980. Root productivity in an Amazonian rain forest. Ecology, 61, 14-18.

KalELA E.K., 1955. Ueber Veraenderungen in den Wurzelverhaeltnissen der Kiefernbestaende in Laufe der Vegetationsperiode. Acta for. fenn., 65 (1), 1-41.

Keyes M.R., Grier C.C., 1981. Above- and belowground net production in 40-year-old Douglas-fir stands on low and high productivity sites. Can. J. Forest Res., 11, 599-605.

Kohmann K., 1972. Root ecological investigations on pine. 1. Problems of methodology and general relationships (original in Norwegian). Meddr norske SkogsforVes., 30, 325-357. (Summary in English.).

KolesNikov V.A., 1968. Cyclic renewal of roots in fruit plants. In : Methods of productivity studies in root systems and rhizosphere organisms, pp. 102-106, Ghilarov M.S. Ed., Publishing House «Nauka», Leningrad.

Köstler J.N., Brücknfr E., Bibelriether H., 1968. Die Warzeln der Waldbaeume, Paul Parey, Hamburg und Berlin.

I.ESHEM B., 1965. The annual activity of intermediary roots of the Aleppo pine. Forest Sci., 11, $291-298$.

LYFORD W.H., 1975. Rhizography of non-woody roots of trees in the forest floor. In : The developinent and function of roots, pp. 179-196, Torrey J. and Clarkson D.T. Eds., Academic Press, New York. 
Lyr H., Hoffmann G., 1967. Growth rates and growth periodicity of tree roots. In : International review of forestry research, pp. 181-236, Romberger J.A. and Mikola P. Eds., Vol. 2, Academic Press, New York and London.

Magnusson C., Schlenius B., 1980. Root consumption in a 15-20 year old Scots pine stand with special regard to phytophagous nematodes. In : Structure and function of northern coniferous forests, pp. 261-268, Persson T. Ed., Ecol. Bull. 32, Swedish Natural Science Research Council, Stockholm.

McArdi. R.E., Meyer W.H., Bruce D., 1949. The yield of Douglas-fir in the Pacific Northwest. Tech. Bull. No. 201, U.S. Department of Agriculture, Washington, D.C.

MCClaugherty C.A., Aber J.D., Mellilo J.M., 1982. The role of fine roots in the organic matter and nitrogen budgets of two forested ecosystems. Ecology, 63, 1481-1490.

MCGINTY D.T., 1976. Comparative root and soil dynamics on a white pine watershed and in the hardwood forest in the Coweeta basin. Ph.D. dissertation, University of Georgia, Athens, GA.

MORrow R.R., 1950. Periodicity and growth of sugar maple surface layer roots. J. For., 48, 875-881.

Neter J., Wasserman W., 1974. Applied linear statistical models - regression, analysis of variance, and experimental designs. Richard D. Irwin, Inc., Homewood, IL.

Ovington J.D., Murray G., 1968. Seasonal periodicity of root growth of birch trees. In : Methods of productivity studies in root systems and rhizosphere organisms, pp. 146-154, Ghilarov M.S. et al. Eds., Publishing House «Nauka», Leningrad.

PERry T.O., 1982. The ecology of tree roots and the practical significance thereof. J. Arboriculture, 8, 197-211.

Persson H., 1978. Root dynamics in a young Scots pine stand in central Sweden. Oikos, 30, $508-519$.

Persson H., 1979. Fine root production, mortality, and decomposition in forest ecosystems. Vegetatio, 41, 101-109.

Persson H., 1980 a. Spatial distribution of fine-root growth, mortality, and decomposition in a young Scots pine stand in central Sweden. Oikos, 34, 77-87.

Persson H., 1980 b. Fine-root dynamics in a Scots pine stand with and without near-optimum nutrient and water regimes. Acta Phytogeogr. suec., 68, 101-110.

Persson H., 1983. The distribution and productivity of fine roots in boreal forests. Pl. Soil., 71, 87-101.

REYNolds E.R.C., 1970. Root distribution and the cause of its spatial variability in Pseudotsuga taxifolia (Poir.) Britt. Pl. Soil, 32, 501-517.

REYNoLDs E.R.C., 1975. Tree rootlets and their distribution. In : The development and function of roots, pp. 163-177, Torrey J. and Clarkson D.T. Eds., Academic Press, New York.

RichaRdSON S.D., 1968. The study of root development in controlled environments. In : Methods of productivity studies in root systems and rhizosphere organisms, pp. 168-176, Ghilarov M.S. et al. Eds., Publishing House «Nauka », Leningrad.

RIEDACKER A., 1976. Rythmes de croissance et de régénération des racines de végétaux ligneux. Ann. Sci. for., 33 (3), 109-139.

Ritchie G.A., Hinckley T.M., 1975. The pressure chamber as an instrument for ecological research. Adv. Ecol. Res., 9, 165-254.

Roberts J., 1976. A study of root distribution and growth in a Pinus sylvestris L. (Scots pine) plantation in East Anglia. Pl. Soil, 44, 607-621.

Russell R.S., 1977. Plant root systems : Their function and interaction with the soil. McGraw-Hill Co. (UK) Ltd., London.

Santantonio D., 1979. Seasonal dynamics of fine roots in mature stands of Douglas-fir of different water regimes - A preliminary report. In : Symposium : Root physiology and symbiosis, pp. 190-203, Riedacker A. and Gagnaire-Michard J. Eds., INRA-CNRF, NancyChampenoux.

Santantonio D., 1982. Production and turnover of fine roots of mature Douglas-fir in relation to site. Ph.D. dissertation, Oregon State University, Corvallis, OR. 
Santanjonio D., Hermann R.K., Overton W.S., 1977. Root biomass studies in forest ecosystems. Pedobiologia, 17, 1-31.

Scholander P.F., Hammel H.T., Bradstreet E.D., Henningsen E.A., 1965. Sap pressure in vascular plants. Science, 148, 339-346.

Sokal R.R., Rohlf F.J., 1969. Biometry. W.H. Freeman \& Co., San Francisco, CA.

Steei. R, Torrie J., 1980. Principles and procedures of statistics - A biometrical approach, 2nd edition, McGraw-Hill, New York.

SutTon R.F., 1969. Form and development of conifer root systems. Tech. Commun. 7, Commonwealth Forestry Bureau, Oxford.

Sutron R.F., 1980. Root system morphogensis. N. Z. J. For. Sci., 10, 264-292.

Teskey R.O., Hinckley T.M., 1981. Influence of temperature and water potential on root growth of white oak. Physiologia Pl., 52, 363-369.

Troughton A., 1974. The growth and function of the root in relation to the shoot. In : Structure and function of primary root tissues, pp. 153-164, Kolek J. Ed., Slovak Academy of Sciences, Bratislava.

Twakowski Z., 1963. Investigations on the annual development dynamics of mycorrhizae in 40-year-old spruce stands (original in Polish). Pr. badaw. Inst. badaw. Lesin., 260, 72-102. (Cited from For. Abstr., 25, 1888 and VoGT et al., 1980).

Vogt K.A., Edmonds R.L., Grier C.C., Piper S.R., 1980. Seasonal changes in mycorrhizal and fibrous-textured root biomass in 23- and 180-year-old Pacific silver fir in western Washington. Can. J. Forest Res., 10, 523-529.

WAID J.S., 1974. Decomposition of roots. In : Biology of plant litter decomposition. pp. 175-212, Dickinson C.H. and Pugh G.J.F. Eds., Academic Press, New York.

Waller H.D, Olson J.S., 1967. Prompt transfers of cesium-137 to the soils of a tagged Liriodendron forest. Ecology, 48, 15-25.

Waring R.H., Franklin J.F., 1979. Evergreen coniferous forests of the Pacific Northwest. Science, 204, 1380-1386.

Zobel D.B., McKee A., Hawk G.M., Dyrness C.T., 1976. Relationships of environment to composition, structure, and diversity of forest communities of the central western Cascades of Oregon. Ecol. Monogr., 46, 135-156. 